Meeting Summary

Published June 17, 2020

\title{
Pathogenesis of Aging and Age-related Comorbidities in People with HIV: HIGHLIGHTS FROM THE HIV ACTION WORKSHOP
}

\section{AUTHORS}

Dana Gabuzda ${ }^{1}$, Beth D. Jamieson ${ }^{2}$, Ronald G. Collman³, Michael M. Lederman ${ }^{4}$, Tricia H. Burdo $^{5}$, Steven G. Deeks ${ }^{6}$, Dirk P. Dittmer ${ }^{7}$, Howard S. Fox ${ }^{8}$, Nicholas T. Funderburg ${ }^{9}$, Savita G. Pahwa $^{10}$, Ivona Pandrea ${ }^{11}$, Cara C. Wilson ${ }^{12}$, Peter W. Hunt ${ }^{6}$

\section{AFFILIATED INSTITUTIONS}

${ }^{1}$ Department of Cancer Immunology and Virology; Dana-Farber Cancer Institute; Boston, Massachusetts; Department of Neurology; Harvard Medical School; Boston, Massachusetts

${ }^{2}$ Department of Medicine; David Geffen School of Medicine; University of California; Los Angeles, California

${ }^{3}$ Department of Medicine; University of Pennsylvania School of Medicine; Philadelphia, Pennsylvania

${ }^{4}$ Department of Medicine; Case Western Reserve University School of Medicine; Cleveland, Ohio ${ }^{5}$ Department of Neuroscience; Lewis Katz School of Medicine; Temple University; Philadelphia, Pennsylvania

${ }^{6}$ Department of Medicine; University of California; San Francisco, California

${ }^{7}$ Department of Microbiology and Immunology; University of North Carolina School of Medicine; Chapel Hill, North Carolina

${ }^{8}$ Department of Pharmacology and Experimental Neuroscience; University of Nebraska Medical Center; Omaha, Nebraska

${ }^{9}$ Division of Medical Laboratory Science; School of Health and Rehabilitation Sciences; Ohio State University College of Medicine; Columbus, Ohio

${ }^{10}$ Department of Microbiology and Immunology; University of Miami Miller School of Medicine; Miami, Florida

${ }^{11}$ Department of Microbiology and Molecular Genetics; School of Medicine; University of Pittsburgh; Pittsburgh, Pennsylvania

${ }^{12}$ Department of Medicine; Division of Infectious Diseases; University of Colorado Anschutz Medical Campus; Aurora, Colorado 
CORRESPONDING AUTHOR

Peter W. Hunt

Department of Medicine

Division of Experimental Medicine

1001 Potrero Ave, Rm 605B

UCSF Box 1234

San Francisco, CA 94110

628-206-8165

peter.hunt@ucsf.edu
DOI

10.20411/pai.v5i1.365

\section{ABSTRACT}

People with HIV (PWH) experience accentuated biological aging, as defined by markers of inflammation, immune dysfunction, and the epigenetic clock. They also have an elevated risk of multiple age-associated comorbidities. To discuss current knowledge, research gaps, and priorities in aging and age-related comorbidities in treated HIV infection, the NIH program staff organized a workshop held in Bethesda, Maryland in September 2019. This review article describes highlights of discussions led by the Pathogenesis/Basic Science Research working group that focused on three high priority topics: immunopathogenesis; the microbiome/virome; and aging and senescence. We summarize knowledge in these fields and describe key questions for research on the pathogenesis of aging and age-related comorbidities in PWH. Understanding the drivers and mechanisms underlying accentuated biological aging is a high priority that will help identify potential therapeutic targets to improve healthspan in older PWH.

Keywords: HIV; aging; inflammaging; cellular senescence; microbiome

\section{INTRODUCTION}

Despite the success of combination antiretroviral therapy (ART) in achieving durable virologic suppression, people with HIV (PWH) are at increased risk for multiple comorbidities associated with aging in the general population, including cardiovascular disease (CVD), lung disease, liver disease, kidney disease, diabetes, neurocognitive disorders, decreased bone mineral density, malignancies, and other diseases [1]. Evidence suggests that treated HIV infection is associated with accentuated aging phenotypes, and these age-related comorbidities can occur at younger ages [2, 3]. The pathophysiologic mechanisms that drive biological aging and age-related comorbidities are not well understood, and the impact of HIV and ART on the biology of aging remains poorly defined. To discuss current knowledge, research gaps, and priorities in HIV-associated comorbidities, a pan-NIH workshop on HIV-associated Comorbidities, Coinfections, and Complications (HIV ACTION) was held in Bethesda, Maryland on September 19-20, 2019. Six working groups were convened and met over the course of a year to prepare for the workshop. This article describes highlights from the planning summaries, talks, and discussions led by the Pathogenesis/ Basic Science Research working group, which focused on the following three high priority topics selected by working group members: 1) Immunopathogenesis; 2) Microbiome/Virome; and 3) Aging and Senescence (Figure 1). Here, we summarize the background, rationale, and key questions for research on the pathogenesis of aging and age-related comorbidities in $\mathrm{PWH}$, and how basic research on these questions might lead to the discovery of new targets for prevention and therapeutic intervention. 


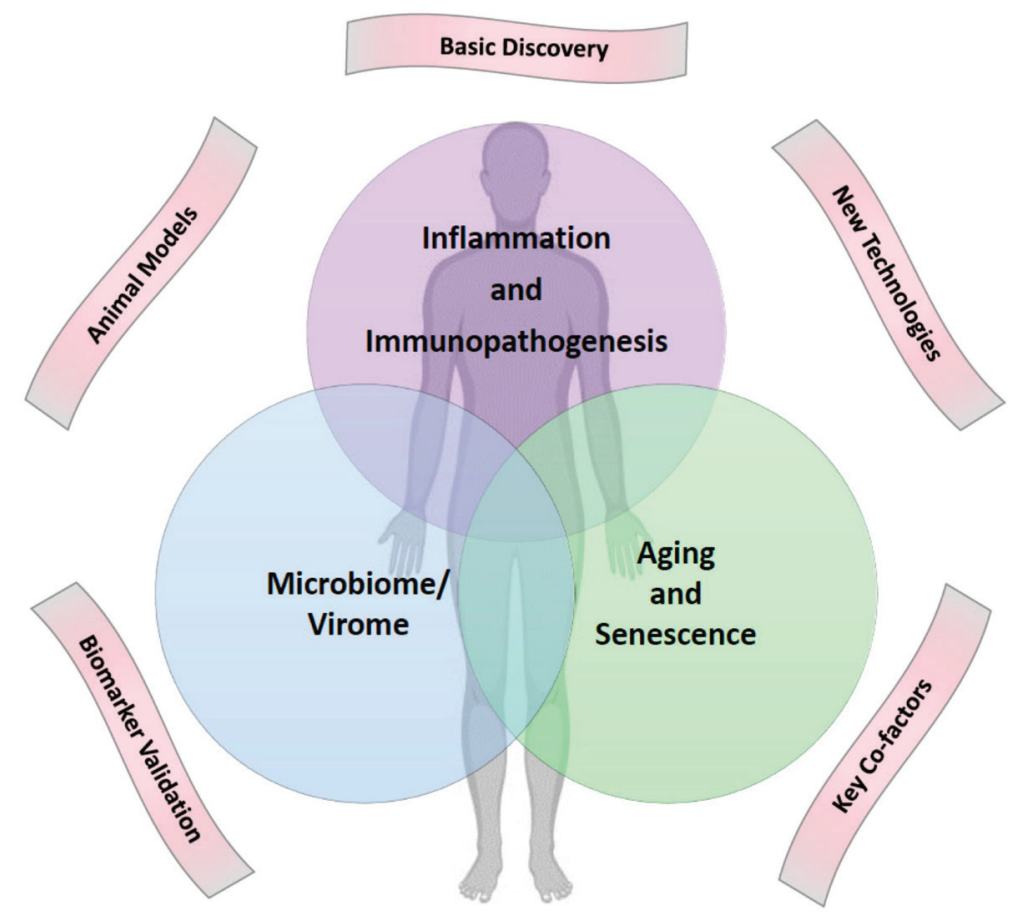

Figure 1. Venn diagram of three high priority topics for research on aging and age-related comorbidities in people with HIV on ART. These three topics were selected by the basic science working group of the HIV ACTION Workshop for presentations and discussion at the workshop. Five cross-cutting themes are shown outside the Venn diagram. Artwork courtesy of Dr. Leia Novak.

\section{Immunopathogenesis and HIV-associated comorbidities Immune activation and inflammation}

Levels of immune activation and inflammation remain elevated in PWH on ART, even when viral suppression has been maintained for several years, and may contribute to morbidity and mortality $[4, \underline{5}]$. Key questions for basic research on immune activation/inflammation and immunopathogenesis related to development of HIV-associated comorbidities are shown in Table 1. Persistent inflammation likely contributes to multiple end-organ diseases in PWH, including CVD, liver, and kidney diseases, neurocognitive disorders, malignancies, and other diseases. While specific mechanisms that underlie each of these comorbidities may involve both shared and unique pathways, biomarkers of immune activation and inflammation (ie, IL-6, sCD14, sCD163, D-dimer, soluble TNF receptors 1 and 2) are broadly associated with development and progression of these comorbidities in PWH [ $[$,, 5$]$. Inflammatory mediators are also linked to development of these comorbidities with aging in uninfected populations. Although definitive evidence establishing a causal role of inflammation in driving disease risk in treated HIV infection is lacking, several lines of evidence support this possibility. A recent clinical trial of the IL-1 $\beta$ inhibitor canakinumab in HIV-uninfected individuals with heart disease showed that reducing inflammation decreases cardiovascular events and mortality from cancer [6]. Furthermore, comparative studies between progressive and non-progressive SIV infections suggest that SIV-induced inflammation contributes to development of CVD and other comorbidities [7]. Persistent inflammation and "inflammaging" (increased inflammation with advancing age) have also been 
identified as likely contributors to frailty $[\underline{8}, \underline{9}]$, a geriatric phenotype related to physical aging. Whether inflammatory profiles associated with increased risk of age-related comorbidities differ between PWH and uninfected populations, and whether their potential mediators and pathways are similar or different, is still unclear.

\section{Table 1. Key Questions for Basic Research on Immunopathogenesis in HIV-associated Co- morbidities}

\section{Key Questions}

\section{What are the drivers of chronic innate and adaptive immune activation in PWH?}

- How do inflammatory profiles of untreated HIV, treated HIV, and comorbidities in the general population differ-or are they superimposable?

- Are drivers of comorbidities in PWH and the aging general population similar-or do different inflammatory pathways drive each towards development of end-organ disease?

- What is the impact of exposure to microbial elements, inflammatory lipids, low-level HIV replication or expression, co-pathogens such as CMV, EBV, HHV-8, HCV, and other human viruses, and inflammatory cytokines that may drive activation, expansion, dysfunction, and altered trafficking/ retention of immune cells in tissues?

- Which inflammatory mediators drive pathology - and which are only markers of immune activation/inflammation?

- How do other exposures (eg, recreational drugs, tobacco, alcohol, etc) affect immune activation and inflammation?

- What are the immune cell and other inflammatory cell subsets with abnormal functions, and how do they contribute to residual immune activation/inflammation and comorbidities during treated HIV infection?

Is residual immune activation/inflammation similar in women and men and, if not, what are the pathways that differ?

Do HIV and ART induce defects in hematopoiesis and tissue sites that ultimately drive chronic immune dysfunction in PWH? For example:

- Tissue sites/reservoirs (lymph node, gut, brain, etc) with residual virus expression that drive immune activation/inflammation under ART?

- Effects of ART regimens on innate and adaptive defense mechanisms?

- Effects of early ART on hematopoiesis, gut, and other organ dysfunctions that could impact inflammatory pathways?

- Can we design studies in uninfected individuals initiating ART as PrEP to untangle the metabolic, neurological, bone, and inflammatory consequences of some ART drugs?

- Effects of ART on hematopoietic malignancies that are severely overrepresented in PWH? 


\section{Can we develop or use tools to predict or identify specific disease pathology?}

- Systemic profiles of soluble and cellular markers of inflammation and coagulation linked to progression of specific disease pathologies?

- Imaging methods that accurately define vascular pathology, neurocognitive impairment, and metabolic diseases including non-alcoholic fatty liver disease (NAFLD)/non-alcoholic steatohepatitis $(\mathrm{NASH})$ ?

- NHP models to define disease pathology and mechanisms of immunopathogenesis in SIV infection that reflect immunopathogenesis in HIV infection?

Can we develop therapeutics to reduce immune activation/inflammation and what should be the main targets for such interventions?

- Should these therapies target elements common to multiple inflammatory pathways activated in HIV disease or should we specifically target more upstream drivers of inflammation, such as specific co-pathogens or inflammatory lipids?

- How will immune-targeted interventions affect host defenses against pathogens, autoimmunity, and malignancy? How will these interventions affect immune homeostasis?

Several potential drivers of chronic inflammation in PWH have been identified, including low-level residual HIV expression during suppressive ART, microbial dysbiosis and translocation, coinfections (eg, cytomegalovirus [CMV], Epstein Barr Virus [EBV], human herpesvirus virus 8 [HHV-8], Hepatitis C virus [HCV]), altered lipid profiles (eg, elevated cholesterol and/or triglycerides, inflammatory oxidized lipids), and lifestyle factors. Each of these potential drivers has been linked to comorbidities in PWH $[\underline{4}, \underline{10}]$. Lifestyle factors such as tobacco smoking, recreational drug use, poor diet, and lack of physical activity along with genetics and coinfections (particularly CMV) have all been linked to low-grade inflammation and development of age-related diseases in the general population (ie, CVD, diabetes, liver disease, age-related cognitive decline). Importantly, many of these lifestyle factors are enriched among PWH [11-14]. Residual immune activation and inflammation, and some other key drivers, may differ between men and women [15], racial/ethnic groups [16], and geographic regions [17] and are likely to be influenced by genetic and environmental factors as well. The list of candidate drivers described here is likely incomplete and requires further study in PWH and uninfected populations to identify root drivers and their relative importance in different settings. To address these questions, animal models are excellent biological systems in which strictly controlled studies can be performed to dissect relative contributions of different factors that are difficult to study in humans. A related question is understanding the distinct patterns of chronic inflammation (ie, "flavors of inflammation") that underlie different organ system comorbidities in different settings. However, not all age-related morbidities are increased by HIV infection (eg, prostate, colon, and breast cancer). Additionally, PWH who start HIV treatment at high CD4 counts may be protected from some morbidities (eg, cardiovascular disease, neurocognitive dysfunction), but remain at abnormally high risk for infections and infection-related malignancies [18]. Understanding the inflammatory pathways responsible for infectious vs non-infectious complications, and the degree to which they persist in individuals who start ART early vs late in the disease course, will be important to identify the most appropriate interventional targets for different settings. 


\section{Immune cell populations and trafficking}

A key issue in immunopathogenesis studies is understanding the effects of HIV and ART on immune cell subsets and their relation to residual immune activation, inflammation, and age-related comorbidities in treated HIV infection. Dysregulation of the immune system due to HIV itself, coinfections, or bystander mediators of inflammation may drive inappropriate activation and retention of immune cells within tissue sites such as blood vessels, liver, adipose tissues, and the central nervous system (CNS). Circulating immune cell populations that include activated monocytes expressing pro-coagulants (eg, tissue factor), as well as increased numbers of mature activated $\mathrm{CD}^{+} \mathrm{T}$ cells that can home to endothelial surfaces via expression of homing receptors including the fractalkine receptor (CX3CR1), lymphocyte function-associated antigen 1 (LFA1), macrophage-1 antigen (Mac-1) [19, 20], C-C chemokine receptor type 2 (CCR2), and type 5 (CCR5) [21], are detected in PWH, and may be linked to development of CVD and other comorbidities [22-26]. Altered migration of activated immune cells to, and retention within, these tissues may also influence development of other end-organ diseases. Additionally, T cell subsets may be inappropriately retained within lymph nodes of $\mathrm{PWH}[\underline{27}]$, potentially contributing to increased lymph node inflammation, fibrosis, and failure of immune cell reconstitution [28, 29]. Some ART drugs may have effects on innate and adaptive defense mechanisms, as well as on hematopoiesis, gut, and other organ dysfunction, which could also influence development of comorbidities. Chemokine receptor antagonists, in particular, may modulate migration of immune

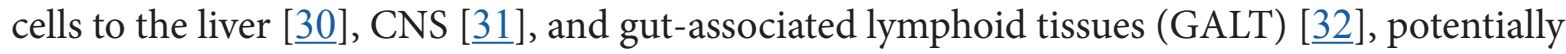
modulating immune activation and end-organ disease. It is important to determine whether HIV and ART induce defects in hematopoiesis that have downstream effects on immune activation, inflammation, and immune dysfunction [33]. Additionally, it will be important to identify the tissue sites/reservoirs (lymph node, gut, brain, etc) responsible for residual virus production that could drive immune activation/inflammation under ART [34]. For such studies, animal models are useful because they allow access to a variety of tissues and use of tagged virus strains that enable detailed characterization of the tissue sites harboring residual virus. Studies involving more limited tissue sampling of PWH will also be important, as the degree of viral suppression in most animal models may not fully reflect the degree of viral suppression in tissues among PWH on long-term ART [35]. Identification of unique biomarker signatures and immune cell populations that predict comorbid conditions will provide insights into mechanisms that drive specific end-organ diseases, and may identify populations that could benefit from personalized prevention and therapeutic strategies.

\section{Targeting upstream drivers of immune activation/inflammation}

Whether disease-associated inflammatory profiles differ in aging PWH and uninfected populations is an important question for development of targeted therapeutic interventions. Although ART prolongs the lifespan of PWH, the quality of life is dampened by side effects of ART including metabolic diseases, decreased bone mineral density, and alterations in lipid profiles and mitochondrial function [ $\underline{36}, \underline{37}]$. Therefore, understanding the effects of ART on the host is important for the optimal design of new strategies to prevent morbidity. It is unclear whether targeting common elements shared by multiple immunopathogenic pathways in treated HIV infection, targeting upstream drivers of activation/inflammation, or direct targeting of the viral reservoir itself will be most effective. It is also unknown whether comorbidities associated with treated HIV infection are driven by overlapping or distinct immunological mechanisms. Studies in uninfect- 
ed individuals initiating ART as pre-exposure prophylaxis (PrEP) and in uninfected nonhuman primate (NHP) models will be important to untangle the metabolic, neurological, bone, and inflammatory consequences of some ART drugs. Clinical intervention trials offer unique opportunities to concurrently test a mechanistic hypothesis and explore potential clinical utility of the intervention, novel readouts, and disease models. Animal models also provide great opportunities to probe interventional strategies, particularly those that have safety concerns or require extensive tissue sampling. For these interventional approaches, it is important to evaluate not just the pathway being targeted, but also parallel inflammatory pathways and/or root drivers that might be affected in either a positive or negative way (ie, the "whack-a-mole" problem) [38]. Addressing these questions will help to define determinants of end-organ disease risk in PWH, targets for intervention, and whether morbid complications of aging in the general population share common pathways with these same outcomes in PWH.

\section{Microbiome/virome in HIV-associated comorbidities HIV-associated changes in the microbiome}

The microbiome consists of the entirety of bacteria, fungi, and viruses that live in concert with the human body, including the gut, respiratory tract, female and male genital tract, oral cavity, skin, and other sites. Among these, the gut microbiome has received the greatest attention. Given the link between inflammation and comorbidities, two observations underlie high interest in the microbiome in HIV infection: (a) the gut microbiome plays a key role in both systemic and local mucosal immunological development and regulation [39-41]; and (b) profound injury to the gut immunological barrier occurs very early in HIV infection, is incompletely repaired with ART, and enables systemic translocation of microbial products that contribute to inflammation [42-45]. Research outside the field of HIV is revealing deep connections between the microbiome, host immunity [46], and function of multiple organ systems, in which dysbiosis is linked to CVD [47], liver disease [48], neurological conditions [49], cancer [50, 51], and other diseases. Metabolome alterations in plasma and other sites may reflect not only microbial products, but also secondary effects of the microbiome on host-derived metabolites mediated through its effects on bile acids, host enzymes, and local mucosal inflammation [ $[\underline{2}, \underline{53}]$. Key questions for research on the microbiome that are relevant for the development of HIV-associated comorbidities are shown in Table 2.

Table 2. Key Questions for Basic Research on the Microbiome/Virome in HIV-associated Comorbidities

\section{Key Questions}

Does the microbiome (bacterial, viral, fungal) play a contributory role in HIV comorbidities?

- Are microbiome changes during HIV infection mainly a consequence of gut epithelial or immune damage, or are they a contributor to, or perpetuator of, this damage, microbial translocation, and/or systemic inflammation and comorbidities?

- Are changes in the virome (gut, plasma, oral, vaginal) contributors to systemic inflammation and/or end-organ comorbidities, or markers of immunological or barrier dysfunction?

- How do HIV-associated microbiome alterations at mucosal sites beyond the gut (eg, lung, 
oral) affect comorbidities such as cancer, chronic lung disease, CVD or CNS disease, or others?

How do other cofactors interact with HIV infection to affect the microbiome and comorbidities?

- Do ART, geography, diet, smoking, sexual behavior, gender, and other factors impact the microbiome and its function in HIV-associated comorbidities?

- How do coinfections, particularly those that are prevalent in resource-poor areas and may be considered part of the "microbiome" in those areas (eg, candida, GI helminths, malaria, $\mathrm{EBV}, \mathrm{HHV}-8$ ) impact comorbidities directly or via effects on the more conventional gut microbiome?

\section{What are the mechanisms of host/HIV/microbiome interactions?}

- What are the responsible mediators (protein, carbohydrate, small-molecule metabolites, etc), and how do microbial products influence the host metabolome and vice-versa? How does ART impact these pathways?

- Beyond taxonomy, what functional changes to the microbiome are involved in these mechanisms?

Can the microbiome in HIV be manipulated to modify these pathways-via replacement, microbe targeting, microbe-directed small-molecule therapeutics, or other approaches? Would such approaches also need to target injured mucosa to achieve sustained impact?

Early reports showed gut microbiome differences in MSM with HIV compared to healthy nonMSM controls [54-57], with subsequent studies clarifying that the microbiome is affected both by HIV infection and by sexual behavior [58-61]. Other factors known to affect the microbiome include geography, diet, coinfections, and age $[\underline{62}, \underline{63}]$, while further research is needed on the effects of ART itself, smoking, gender, etc. While the changes seen in PWH vary between studies, a common theme includes decreased diversity and relative enrichment of certain taxa and depletion of others [61]. Several organisms enriched in HIV-associated gut microbiomes have proinflammatory properties [64]. The degree of dysbiosis is also linked to immune status and systemic inflammation [65-68]. Coinfections, particularly those that are prevalent in resource-poor areas and may also be considered part of the "microbiome" in those geographic regions (eg, candida, GI helminths, malaria, EBV, HHV-8), are linked to comorbidities, vaccine response, and HIV transmission either directly or via effects on the conventional gut microbiome. Fecal metabolome profiles are also altered, including tryptophan and bile acid metabolism $[\underline{55}, \underline{69}, \underline{70}]$. In the SIV macaque model of AIDS, marked expansion of the enteric virome has been reported [71], with some changes also identified in $\mathrm{PWH}[\underline{57}, \underline{59}]$.

The microbiome has been implicated as a contributing factor to CVD in the general population, via metabolism of dietary nutrients by gut microbiota to trimethylamine (TMA), which is converted to trimethylamine $\mathrm{N}$-oxide (TMAO), which has direct effects on the heart and vasculature as well as kidney and other organs $[\underline{72}, \underline{73}]$. Other microbiome-related pathways have been implicated in animal models and human populations in gastrointestinal, liver [4] ], neurobehavioral 
[49], metabolic, neoplastic [ $\underline{50}, \underline{51}]$, and other diseases. Many of these findings involve pathways mediated by systemic inflammation and/or microbial metabolite alterations, although local microbiome populations have also been implicated in development of cancers and lung disease [74-76]. The microbiome is a key determinant of the integrity and function of the gut mucosal barrier $[\underline{77}, \underline{78}]$, and is a major target of therapeutics in inflammatory bowel disease $[\underline{79}, \underline{80}]$. In HIV infection, alterations in the microbiome and metabolites that are affected by microbes, such as TMAO and kynurenines, have been linked to CVD and liver disease [ $[\underline{5}, \underline{81-83}]$, although not all studies agree [84]. Some of these pathways have also been linked to neurocognitive or psychiatric comorbidities [85-87]. ART can alter some of these microbiome-related pathways [88-90]. However, it remains to be determined whether microbiome changes identified in HIV infection are cause or consequence. Are they simply a reflection of gut epithelial or immune damage, or do they contribute to or perpetuate such damage, systemic inflammation, and comorbidities?

Because the field of microbiome research is relatively new, the working group considered the overarching question of whether research on microbiome/HIV comorbidities should be carried out contemporaneously with research on related comorbidities outside of the HIV context. While this discussion is focused on HIV comorbidities, the close link between comorbidities and inflammation, the microbiome's role in the development and regulation of immune function, and links between inflammation and immunopathogenesis means that many of the questions raised here are pertinent to whether the microbiome impacts immunopathogenesis, including immune recovery following ART. The microbiome may also be important in other key aspects of HIV disease apart from comorbidities, such as transmission (through the female and male genital tracts $[91,92]$ ), prevention (vaccine efficacy affected by gut microbiome $[93,94]$, and microbicide activity affected by vaginal microbiome [95]). With recent evidence that the microbiome can modulate the effects of immunotherapy in cancer [96-98], it is reasonable to ask whether microbial populations will determine responses to immunotherapy targeting morbidity and HIV eradication.

\section{Microbiome as potential therapeutic target}

Interventional studies have not yet demonstrated a clear impact of the microbiome on systemic inflammation in PWH. For example, a recent study of the probiotic Visbiome failed to find alterations in any systemic markers of immune activation in treated HIV infection [99]. Host metabolome profiles appear to differ in PWH compared to those in uninfected people, and some of these differences may determine the risk of some comorbidities. Thus, identifying the key microbiome-related pathways that could most strongly drive disease risk (and how best to alter them) has the potential to improve the effectiveness of targeted microbial-directed therapy. Given rapid progress in research on microbiome-organ interactions and health consequences, focused efforts in the context of HIV can leverage that progress to accelerate discoveries that might ameliorate comorbidities. Incorporating microbiome/virome/fungome and metabolome measurements into comorbidity-focused HIV clinical trials could provide a platform that will help to advance such discovery.

Microbiome research in animal models has been valuable in fields outside of HIV (eg, inflammatory bowel disease, diabetes, obesity, mood/anxiety disorders, etc). SIV-infected NHPs are the best model for HIV pathogenesis, but these models are logistically more challenging and costly than small animal models, and the human and NHP microbiomes have important differences. Small animal models for studies of the microbiome that are more reflective of the human condi- 
tion are important for defining microbiome-organ interactions in health and disease. Thus, a mix of small animal, NHP, and human studies are needed to advance the field, and to discover, develop, and model interactions between the microbiome and comorbidities. Further studies are also needed to determine whether the microbiome can be manipulated to modify these pathways-via replacement, microbe targeting, microbe-directed small molecule therapeutics, or other approaches-and whether such approaches also need to target the injured mucosa to achieve sustained impact on immune function and disease outcomes.

\section{Aging and Cellular Senescence in HIV}

\section{Is aging accentuated or accelerated in HIV?}

Despite the positive effects of ART on longevity, lifespans of PWH may still fall short of the general population's $[\underline{100}]$ and is characterized by an increased risk for earlier development of age-associated comorbidities [101-103]. Aging can manifest at the level of inflammation, immune response, and cellular senescence in any organ system. Additionally, aging affects both immune surveillance of cancer cells and cell-intrinsic DNA integrity, leading to an exponential increase in malignancies with age.

PWH exhibit declines, at a significantly younger age, in gait speed [104] and grip strength [105], consistent with increased incidence of frailty-related phenotypes [106] and frailty [107]. In addition to HIV and ART, other factors that may affect biological aging in PWH include sociodemographic, socioeconomic, and/or behavioral factors (Figure 2) [108]. While HIV does not necessarily increase the rate at which these complications increase with advancing age (ie, accelerated aging), the higher risk of age-related multi-morbidity and functional decline at any given age among PWH is consistent with an accentuated aging model [109].

\section{Drivers and Mechanisms of Aging with HIV and ART}

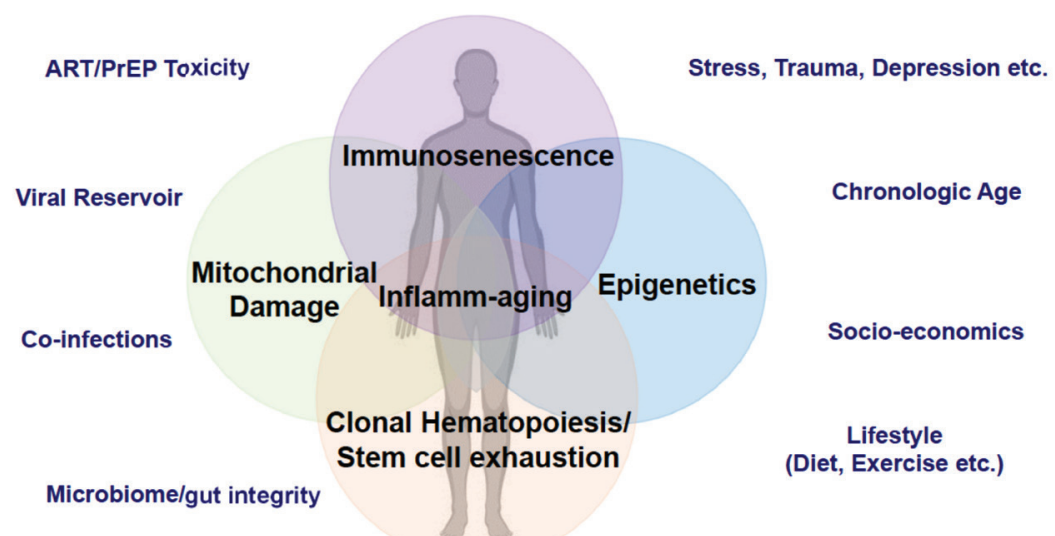

Figure 2. Venn diagram of drivers and mechanisms of aging in people with HIV on ART. These drivers and mechanisms of aging and their relationship to age-related comorbidities and the discovery of potential therapeutic targets in people with HIV were topics highlighted at the HIV ACTION workshop. Modified from artwork courtesy of Dr. Leia Novak. Abbreviations: ART, antiretroviral therapy; PrEP, pre-exposure prophylaxis. 
Treated HIV infection, like aging, is associated with increased inflammatory and coagulation markers which, in turn, are associated with increased risk of many aging-related comorbidities and mortality [110]. Nevertheless, immunologic predictors of age-related complications may be different in people with and without HIV. For example, the magnitude of the IL-2 response by $\mathrm{CD}^{+} \mathrm{T}$ cells in response to stimulation by CMV peptides predicts frailty onset in uninfected men, but fails to do so in men with HIV [111]. Similarly, CD8+ T cell phenotypes associated with immunosenescence (CD28-CD57+) predict mortality in HIV-uninfected elderly individuals, but not in PWH $[\underline{112}, \underline{113}]$. Higher rates of tobacco smoking, recreational drug use, depression, stigma, and trauma in PWH may also contribute to observed differences in people with versus without HIV [114]. Despite the difficulty in assessing whether HIV infection accelerates or accentuates aging, the number of people aging with HIV infection continues to increase; therefore, understanding these interactions is critical to the rational design of therapies to increase both the healthspan and lifespan of PWH as they age.

Key questions for research on aging and cellular senescence in relation to development of HIV-associated comorbidities are shown in Table 3. Discussions focused on whether the etiology of aging-related inflammation differs between PWH and uninfected individuals, and how "inflammaging" is influenced by biological sex, as well as by coinfections, lifestyle, sociodemographic/socioeconomic status, neuropsychiatric conditions (depression, addictions, etc), and/or behavioral factors. The deleterious influence of inflammation and immune activation on immune function as evaluated by vaccine responses in the context of age and HIV infection was discussed [115-118]. Other discussions included the influence of ART on drivers of inflammation, and whether newer, current ART regimens contribute to the inflammatory environment through mitochondrial toxicities or other mechanisms. Evidence suggests that some non-reversible pretreatment pathologies (eg, lymphoid fibrosis, GALT disruption) [119], along with CMV or other coinfections (eg, $\mathrm{HCV})$, contribute to inflammation and age-associated comorbidities of aging $[\underline{120}, \underline{121}]$. However, it remains unclear whether these factors are causal or only associated.

\section{Table 3. Key Questions for Basic Research on Aging and Senescence in HIV Infection}

\section{Key Questions}

\section{Do the mechanisms and mediators of age-related end-organ diseases (ie, sarcopenia, neuro- cognitive dysfunction, malignancies, etc) differ in aging with and without HIV and ART?}

- How are inflammatory pathways and their root causes similar or different with regard to their profiles and contributions to age-related comorbidities in the presence or absence of HIV?

- Does the etiology of aging-related inflammation differ between PWH and uninfected individuals? How is it influenced by gender, coinfections, lifestyle, sociodemographic and socioeconomic status, neuropsychiatric conditions (depression, addiction, etc), and/or behavioral factors?

- How does ART influence drivers of inflammation, and does it introduce any new sources or exacerbate existing ones? To what extent do newer current ART regimens in-duce mitochondrial toxicities and contribute to the inflammatory milieu after ART initiation? 
- How do non-reversible pretreatment alterations (eg, lymphoid fibrosis, GALT disruption) contribute to inflammation and comorbidities of aging?

- What is the role of CMV or other infections (eg, HCV, EBV, HHV-8) in inflammation and comorbidities of aging? Is it causal or only correlated?

- How do neuropsychiatric conditions over-represented in PWH (eg, depression and addiction) contribute to inflammaging and comorbidities?

Why are senescent, terminally differentiated and activated $\mathrm{T}$ cells, particularly CD8+ T cells, associated with comorbidities in the elderly and with accelerated epigenetic aging in HIV infection? Are they causative, contributory, or only correlative? Would senolytics change this landscape in the presence or absence of HIV?

- Is inflammation the major driving force behind the accelerated epigenetic aging observed in $\mathrm{PWH}$, and if so, what underlying mechanism(s) elicits these changes?

Can we identify lifestyle, behavioral, and environmental variables that positively modify the epigenetic, mitochondrial, and inflammatory background in successfully treated $\mathrm{PWH}$, and do these variables differ in their impact in PWH vs uninfected adults in mitigating morbidities and mortality?

- What are the long-term consequences of an accelerated aging epigenome in PWH?

- Using epigenetics, can we find genes or intersecting pathways that are prognostic for morbidities/mortality, thus allowing - not only for discovery of biomarkers of impending disease and death-but for novel pharmaceutical intervention strategies?

What role does damage to critical hematopoietic stem cell niches and lymphoid microenvironments by HIV and ART play in age-related comorbidities, especially younger onset of malignancies and their more aggressive clinical presentation?

\section{Evidence of premature aging from epigenetic clock studies}

Studies of the "epigenetic clock" provide evidence suggesting greater advancement of biological aging in PWH. In particular, untreated HIV infection results in an average advancement of DNA methylation age in peripheral blood mononuclear cells (PBMC) of $\sim 8.4$ years or more according to the original "epigenetic clock" and $~ 5.9$ years by the newer GrimAge epigenetic clock, which predicts morbidity and mortality [122]. Non-aging related genes are also epigenetically modified, potentially pointing towards unique insults that HIV infection might bring to the development of morbidities and mortality. However, these epigenetic changes and their biological significance remain largely unexplored. Two years of ART treatment only moderately readjust the PBMC epigenetic clock to more age-appropriate patterns. For example, one study found that ART-treated individuals may remain epigenetically older by $\sim 5$ years for even longer than two years post-ART $[122,123]$. Studies looking at longer ART duration, timing of ART initiation, age at infection and ART initiation, and identifying new potentially deleterious epigenetic changes introduced by ART are still needed. Additionally, newer epigenetic clocks are being tested in uninfected populations to predict morbidity and mortality and to identify modifiers that might decrease the risk of these outcomes. 
Is inflammation the major driving force behind the accelerated epigenetic clock observed in PWH, and if so, what are the underlying mechanisms that elicit these changes? To understand how biological aging influences age-related comorbidities in older $\mathrm{PWH}$, it will be important to evaluate epigenetic changes in relevant tissues and in specific immune cell types, as the inflammatory milieu may differ by site, organ, and cell type. Knowledge gained from analyses of these epigenetic changes in specific cell types and organs can then be leveraged to address the above questions and potentially accelerate intervention research.

The utility of these epigenetic changes as a biomarker for efficacy of treatment is uncertain, as there is no evidence that reversing these epigenetic changes is associated with better outcomes, but it warrants further study. Specific epigenetic changes unique to HIV have been identified [123]. These epigenetic changes could then be evaluated to determine whether an intervention can alter health outcomes, long-term consequences of epigenetic aging markers in $\mathrm{PWH}$, and genes or intersecting pathways that are prognostic for morbidities and mortality. This approach might allow not only for discovery of biomarkers of impending disease and death, but also for discovery of novel intervention strategies.

\section{Aging, senescence, inflammation, and age-related comorbidities}

During aging in the general population, as the risk of morbidities and mortality increases, lifestyle factors, psychological stress, mental health, environmental toxins, chronic infections such as CMV, and a "leaky" gut can set up a background of inflammation that increases with advancing age (inflammaging) mediated through oxidative stress, mitochondrial damage (mtDNA, formylated peptides), and cellular activation/proliferation $[\underline{124}, \underline{125}]$. Many of these mechanisms also drive induction of senescent cells [126], with a senescence-associated secretory phenotype [SASP] [127] that in turn can elaborate proinflammatory molecules and exacerbate inflammaging [128]. SASP of senescent cells can thus promote the development of comorbid conditions such as insulin resistance and CVD [129]. A multitude of factors listed above has been implicated in acquisition of SASP by senescent cells; in addition to DNA damage, telomeric dysfunction, and epigenetic changes, these factors also include social stress, lifestyle, environment, and chronic infections. These concepts are discussed in the field of geroscience, which links aging to chronic diseases $[130,131]$. Senescent, terminally differentiated, and activated T cells, particularly CD $8^{+} \mathrm{T}$ cells, are associated with morbidity and mortality in the elderly.

In PWH, accumulation of senescent cells is associated with advancement of epigenetic aging, though it is unclear whether they play a causative or contributory role or are only correlative. Other contributing factors that may promote biological aging and age-related comorbidities in HIV include antigen-driven proliferation, shortening of telomeres, accumulation of DNA damage, disruption of the stem cell niche, and stem cell exhaustion $[\underline{33}, \underline{108}, \underline{132}]$. The end result of these processes is an environment that promotes low-grade inflammation, along with decreased lymphoid progenitors and an accumulation of senescent lymphocytes with less diverse T cell repertoires [133-136]. Unlike lymphoid progenitors, myeloid progenitors are not diminished, which may contribute to increased incidence of anemias and myeloid dysplasias [137, 138]. Damage to critical hematopoietic stem cell niches and lymphoid microenvironments by HIV and ART may promote some HIV-associated comorbidities, such as younger onset or more aggressive presentation of some malignancies. HIV infection exacerbates these parameters, adding additional uncharacterized physiological stressors that may not be fully resolved by ART, and creating a sce- 
nario in which biological aging could be accentuated or accelerated [108]. It will be important to identify lifestyle, behavioral, and environmental factors that modify the epigenetic and inflammatory background in treated HIV and determine whether their impact on morbidities and mortality is different in PWH vs uninfected adults. Understanding the senescent cells and SASPs that are most directly linked to chronic inflammation and comorbid conditions in older PWH may also help to identify pathways that could serve as anti-inflammatory therapeutic targets.

\section{Potential therapeutic targets to improve "healthspan" in older PWH}

Understanding how HIV and ART affect physiological and health deficits associated with aging and exacerbate age-associated comorbidities may be key to identifying potential therapeutic targets that improve "healthspan" (ie, longer healthy life without significant comorbidities). A new therapeutic area is that of senotherapeutics for HIV and aging (reviewed in [139]). The demonstration in murine aging models that targeting of senescent cells can result in increased healthspan and lifespan [140] has prompted a variety of pharmacologic strategies to kill senescent cells (senolytic agents) or counteract senescence (reviewed in [139]). This rapidly developing field holds the promise of identifying compounds that target processes underlying cellular senescence and perhaps slowing aging-associated morbidities [141]. The first human trial of senolytics in patients with idiopathic pulmonary fibrosis (NCT02874989) investigated dasatinib (a tyrosine kinase inhibitor or TKI) in combination with quercetin (a plant flavanol that targets BCL-2, insulin/IGF-1, and HIF1-alpha), demonstrating the safety and tolerability of these compounds in association with improved physical function [142]. The role of these agents in the setting of HIV infection is not established and should be explored cautiously. Notable senolytics include BCL-2 antagonists, metformin, mTOR inhibitors, and Jak-1 and 2 inhibitors. The BCL-2 inhibitor venetoclax is being investigated for its role as a senolytic, and for its influence on HIV reservoirs. In animal models of aging, the efficacy of metformin led to the Targeting Aging with Metformin (TAME) Trial (managed by the American Foundation for Aging Research), investigating this drug as a novel senotherapeutic in HIV-uninfected persons. A small study (NCT02659306) with this compound [143] is being conducted in Canada in PWH to test whether its anti-inflammatory activity can reduce HIV reservoirs. Another interesting pharmacologic agent is the mTOR inhibitor rapamycin, which has been shown to prolong the lifespan of mammalian species [144], possibly due in part to improved effector cell responses. Everolimus, a rapamycin analog, administered with the seasonal influenza vaccine, improved vaccine responses in elderly participants [145]. Ruxolitinib, a Janus kinase (JAK) 1 and 2 inhibitor (FDA-approved for treatment of myeloproliferative disorders) has been investigated in a randomized phase 2 clinical trial in $60 \mathrm{PWH}$ on ART (NCT02475655) and results of this trial are awaited.

Humans and NHPs on long-term ART can be studied to address many of these questions using newer technologies such as high-throughput omics platforms, assays for measuring mtDNA copy number and mitochondrial genetic variability, and multiplexed assays for quantifying inflammatory biomarkers that have expanded our ability to undertake a comprehensive integrated approach. Humanized mice and organoid models are also likely to be valuable in elucidating the effects of HIV and ART on various organs and tissues at the cellular and molecular level. Studies in the more closely genetically related NHP models that can be successfully treated with ART and develop SIV-related comorbidities [146] are also valuable to decipher pathways responsible for accentuated aging and end-organ disease. While studies on NHPs have translational potential for 
disease-related research [147], studies on aging with HIV/SIV have been limited to comparing infections of young and old animals $[\underline{148}, \underline{149}]$. Epigenetic and other aging biomarkers described above can be incorporated into these studies to fill gaps in our scientific knowledge about biological aging and perhaps identify new approaches to improve healthy aging in $\mathrm{PWH}$. To improve the lives of PWH, it will be important to determine which markers of accentuated aging are epiphenomena that might be useful markers of outcome and which contribute to pathogenesis that could serve as targets for intervention.

\section{CONCLUSIONS}

We have reviewed evidence suggesting that people with HIV experience accentuated biological aging that is reflected by increased risk of many age-associated comorbidities, frailty, early mortality, persistent inflammatory states, and epigenetic markers of aging. HIV-specific factors that may influence biological aging in PWH on long-term ART include persistent low-level viral expression, increased gut permeability and dysbiosis of the microbiome/virome, direct effects of some ART drugs, and coinfections such as CMV and HCV. Moving forward, basic research, together with studies in NHP and small animal models, will help to develop a more complete mechanistic understanding of aging phenotypes that are affected by HIV and ART and make use of this knowledge to discover new targets for prevention and therapeutic intervention.

\section{ACKNOWLEDGMENTS}

We would like to acknowledge the National Institutes of Health (NIH), particularly the workshop's primary sponsors and contributors, the National Heart, Lung, and Blood Institute (NHL$\mathrm{BI}$ ) and the Office of AIDS Research (OAR), as well as the additional 19 NIH co-sponsors and contributors: the Fogarty International Center (FIC); the National Cancer Institute (NCI); the National Institute on Aging (NIA); the National Institute on Alcohol Abuse and Alcoholism (NIAAA); the National Institute of Allergy and Infectious Diseases (NIAID); the Eunice Kennedy Shriver National Institute of Child Health and Human Development (NICHD); the National Institute on Drug Abuse (NIDA); the National Institute on Deafness and Other Communication Disorders (NIDCD); the National Institute of Dental and Craniofacial Research (NIDCR); the National Institute of Diabetes and Digestive and Kidney Diseases (NIDDK); the National Institute of Mental Health (NIMH); the National Institute on Minority Health and Health Disparities (NIMHD); the National Institute of Neurological Disorders and Stroke (NINDS); the National Institute of Nursing Research (NINR); the National Library of Medicine (NLM); the Office of Behavioral and Social Sciences Research (OBSSR); the Office of Disease Prevention (ODP); the Office of Research Infrastructure Programs (ORIP); and the Office of Research on Women's Health (ORWH).

We would also like to acknowledge the workshop's organizers from the NIH, Shimian Zou (NHLBI), Natalie Tomitch (OAR), and Leia Novak (NIAID). We would also like to acknowledge Leia Novak (NIAID) and Lis Caler (OAR) for organizing and coordinating our working group as well, participating in the discussions along with the other members of our working group that represented the NIH, Ronald Adkins (ORIP), Peter Perrin (NIDDK), Vasudev Rao (NIMH), May Wong (NINDS), and Shimian Zou (NHLBI). We also acknowledge Judith Campisi, Russell Tracy, and Steve Wakefield for helpful discussions, and thank Leia Novak for preparing figures and supporting the working group's efforts through all stages of workshop organization and manuscript preparation. 


\section{FUNDING}

Manuscript preparation was supported in part by NIH R01 DA046203 (DG), R01AI110271 (PWH), R33-HL137063 (RGC), R01-DA044906 (RGC), R01 CA228172 (DPD), and R01HL123096 (IP).

\section{POTENTIAL CONFLICTS OF INTEREST}

Nicholas Funderberg serves as a consultant for Gilead. Michael M. Lederman is the senior editor for Pathogens and Immunity. Steven G. Deeks, Dirk P. Dittmer, Nicholas T. Funderburg, and Peter W. Hunt serve as associate editors for Pathogens and Immunity.

\section{AUTHOR CONTRIBUTIONS}

All authors contributed to drafting and editing the manuscript, and approved the final manuscript.

\section{REFERENCES}

1. Schouten J, Wit FW, Stolte IG, Kootstra NA, van der Valk M, Geerlings SE, Prins M, Reiss P, Group AGCS. Cross-sectional comparison of the prevalence of age-associated comorbidities and their risk factors between HIV-infected and uninfected individuals: the AGEhIV cohort study. Clin Infect Dis. 2014;59(12):1787-97. PubMed PMID. doi: 10.1093/cid/ciu701

2. Hawkins KL, Brown TT, Margolick JB, Erlandson KM. Geriatric syndromes: new frontiers in HIV and sarcopenia. AIDS. 2017;31 Suppl 2:S137-S46. PubMed PMID: PMC5693390. doi: 10.1097/QAD.0000000000001444

3. De Francesco D, Sabin CA, Reiss P. Multimorbidity patterns in people with HIV. Curr Opin HIV AIDS. 2019. PubMed PMID. doi: 10.1097/COH.0000000000000595

4. Bowman E, Funderburg NT. Lipidome Abnormalities and Cardiovascular Disease Risk in HIV Infection. Curr HIV/AIDS Rep. 2019;16(3):214-23. PubMed PMID: PMC6579629. doi: 10.1007/s11904-019-00442-9

5. De Francesco D, Wit FW, Burkle A, Oehlke S, Kootstra NA, Winston A, Franceschi C, Garagnani P, Pirazzini C, Libert C, Grune T, Weber D, Jansen E, Sabin CA, Reiss P, the Co-morBidity in Relation to AC. Do people living with HIV experience greater age advancement than their HIV-negative counterparts? AIDS. 2019;33(2):259-68. PubMed PMID: PMC6319574. doi: 10.1097/QAD.0000000000002063

6. Ridker PM, Everett BM, Thuren T, MacFadyen JG, Chang WH, Ballantyne C, Fonseca F, Nicolau J, Koenig W, Anker SD, Kastelein JJP, Cornel JH, Pais P, Pella D, Genest J, Cifkova R, Lorenzatti A, Forster T, Kobalava Z, Vida-Simiti L, Flather M, Shimokawa H, Ogawa H, Dellborg M, Rossi PRF, Troquay RPT, Libby P, Glynn RJ, Group CT. Antiinflammatory Therapy with Canakinumab for Atherosclerotic Disease. N Engl J Med. 2017;377(12):1119-31. PubMed PMID. doi: 10.1056/NEJMoa1707914

7. Pandrea I, Cornell E, Wilson C, Ribeiro RM, Ma D, Kristoff J, Xu C, Haret-Richter GS, Trichel A, Apetrei C, Landay A, Tracy R. Coagulation biomarkers predict disease progression in 
SIV-infected nonhuman primates. Blood. 2012;120(7):1357-66. PubMed PMID: PMC3423778. doi: 10.1182/blood-2012-03-414706

8. Margolick JB, Bream JH, Martinez-Maza O, Lopez J, Li X, Phair JP, Koletar SL, Jacobson LP. Frailty and Circulating Markers of Inflammation in HIV+ and HIV- Men in the Multicenter AIDS Cohort Study. J Acquir Immune Defic Syndr. 2017;74(4):407-17. PubMed PMID: PMC5365031. doi: 10.1097/QAI.0000000000001261

9. Erlandson KM, Allshouse AA, Jankowski CM, Lee EJ, Rufner KM, Palmer BE, Wilson CC, MaWhinney S, Kohrt WM, Campbell TB. Association of functional impairment with inflammation and immune activation in HIV type 1-infected adults receiving effective antiretroviral therapy. J Infect Dis. 2013;208(2):249-59. PubMed PMID: PMC3685225. doi: 10.1093/infdis/jit147

10. Desquilbet L, Jacobson LP, Fried LP, Phair JP, Jamieson BD, Holloway M, Margolick JB, Multicenter ACS. HIV-1 infection is associated with an earlier occurrence of a phenotype related to frailty. J Gerontol A Biol Sci Med Sci. 2007;62(11):1279-86. PubMed PMID. doi: 10.1093/ gerona/62.11.1279

11. Helleberg M, Afzal S, Kronborg G, Larsen CS, Pedersen G, Pedersen C, Gerstoft J, Nordestgaard BG, Obel N. Mortality attributable to smoking among HIV-1-infected individuals: a nationwide, population-based cohort study. Clin Infect Dis. 2013;56(5):727-34. PubMed PMID. doi: $10.1093 / \mathrm{cid} / \mathrm{cis} 933$

12. Ikeda ML, Barcellos NT, Alencastro PR, Wolff FH, Moreira LB, Gus M, Brandao AB, Fuchs FD, Fuchs SC. Alcohol Drinking Pattern: A Comparison between HIV-Infected Patients and Individuals from the General Population. PLoS One. 2016;11(6):e0158535. PubMed PMID: PMC4928875. doi: 10.1371/journal.pone.0158535

13. Garin N, Velasco C, De Pourcq JT, Lopez B, Gutierrez Mdel M, Haro JM, Feliu A, Mangues MA, Trilla A. Recreational drug use among individuals living with HIV in Europe: review of the prevalence, comparison with the general population and HIV guidelines recommendations. Front Microbiol. 2015;6:690. PubMed PMID: PMC4500990. doi: 10.3389/fmicb.2015.00690

14. Castro JG, Alcaide ML. High Rates of STIs in HIV-Infected Patients Attending an STI Clinic. South Med J. 2016;109(1):1-4. PubMed PMID: PMC4705853. doi: 10.14423/ SMJ.0000000000000389

15. Scully EP. Sex Differences in HIV Infection: Mystique Versus Machismo. Pathog Immun. 2018;3(1):82-113. PubMed PMID: PMC6103226. doi: 10.20411/pai.v3i1.238

16. Hackler E, 3rd, Lew J, Gore MO, Ayers CR, Atzler D, Khera A, Rohatgi A, Lewis A, Neeland I, Omland T, de Lemos JA. Racial Differences in Cardiovascular Biomarkers in the General Population. J Am Heart Assoc. 2019;8(18):e012729. PubMed PMID: PMC6817997. doi: 10.1161/ JAHA.119.012729

17. Kityo C, Makamdop KN, Rothenberger M, Chipman JG, Hoskuldsson T, Beilman GJ, Grzywacz B, Mugyenyi P, Ssali F, Akondy RS, Anderson J, Schmidt TE, Reimann T, Callisto SP, Schoephoerster J, Schuster J, Muloma P, Ssengendo P, Moysi E, Petrovas C, Lanciotti R, Zhang L, Arevalo MT, Rodriguez B, Ross TM, Trautmann L, Sekaly RP, Lederman MM, Koup 
RA, Ahmed R, Reilly C, Douek DC, Schacker TW. Lymphoid tissue fibrosis is associated with impaired vaccine responses. J Clin Invest. 2018;128(7):2763-73. PubMed PMID: PMC6025977. doi: 10.1172/JCI97377

18. Hunt PW, Lee SA, Siedner MJ. Immunologic Biomarkers, Morbidity, and Mortality in Treated HIV Infection. J Infect Dis. 2016;214 Suppl 2:S44-50. PubMed PMID: PMC5021241. doi: 10.1093/infdis/jiw275

19. Kulkarni M, Bowman E, Gabriel J, Amburgy T, Mayne E, Zidar DA, Maierhofer C, Turner AN, Bazan JA, Koletar SL, Lederman MM, Sieg SF, Funderburg NT. Altered Monocyte and Endothelial Cell Adhesion Molecule Expression Is Linked to Vascular Inflammation in Human Immunodeficiency Virus Infection. Open Forum Infect Dis. 2016;3(4):ofw224. PubMed PMID: PMC5198584. doi: 10.1093/ofid/ofw224

20. Bowman ER, Kulkarni M, Gabriel J, Cichon MJ, Riedl K, Belury MA, Lake JE, Richardson B, Cameron C, Cameron M, Koletar SL, Lederman MM, Sieg SF, Funderburg NT. Altered Lipidome Composition Is Related to Markers of Monocyte and Immune Activation in Antiretroviral Therapy Treated Human Immunodeficiency Virus (HIV) Infection and in Uninfected Persons. Front Immunol. 2019;10:785. PubMed PMID: PMC6477036. doi: 10.3389/fimmu.2019.00785

21. D’Antoni ML, Mitchell BI, McCurdy S, Byron MM, Ogata-Arakaki D, Chow D, Mehta NN, Boisvert WA, Lefebvre E, Shikuma CM, Ndhlovu LC, Baumer Y. Cenicriviroc inhibits trans-endothelial passage of monocytes and is associated with impaired E-selectin expression. J Leukoc Biol. 2018;104(6):1241-52. PubMed PMID: PMC6258344. doi: 10.1002/JLB.5A0817-328RRR

22. Desquilbet L, Margolick JB, Fried LP, Phair JP, Jamieson BD, Holloway M, Jacobson LP, Multicenter ACS. Relationship between a frailty-related phenotype and progressive deterioration of the immune system in HIV-infected men. J Acquir Immune Defic Syndr. 2009;50(3):299-306. PubMed PMID: PMC2699396. doi: 10.1097/QAI.0b013e3181945eb0

23. Duffau P, Ozanne A, Bonnet F, Lazaro E, Cazanave C, Blanco P, Riviere E, Desclaux A, Hyernard C, Gensous N, Pellegrin I, Wittkop L. Multimorbidity, age-related comorbidities and mortality: association of activation, senescence and inflammation markers in HIV adults. AIDS. 2018;32(12):1651-60. PubMed PMID. doi: 10.1097/QAD.0000000000001875

24. Erlandson KM, Ng DK, Jacobson LP, Margolick JB, Dobs AS, Palella FJ, Jr., Lake JE, Bui $\mathrm{H}$, Kingsley L, Brown TT. Inflammation, Immune Activation, Immunosenescence, and Hormonal Biomarkers in the Frailty-Related Phenotype of Men With or at Risk for HIV Infection. J Infect Dis. 2017;215(2):228-37. PubMed PMID: PMC5897840. doi: 10.1093/infdis/jiw523

25. Funderburg NT, Zidar DA, Shive C, Lioi A, Mudd J, Musselwhite LW, Simon DI, Costa MA, Rodriguez B, Sieg SF, Lederman MM. Shared monocyte subset phenotypes in HIV-1 infection and in uninfected subjects with acute coronary syndrome. Blood. 2012;120(23):4599-608. PubMed PMID: PMC3512236. doi: 10.1182/blood-2012-05-433946

26. Pallikkuth S, Pahwa R, Kausalya B, Saravanan S, Pan L, Vignesh R, Iqbal S, Solomon SS, Murugavel KG, Poongulali S, Kumarasamy N, Pahwa S. Cardiac morbidity in HIV infection is associated with checkpoint inhibitor LAG-3 on CD4 T cells. PLoS One. 2018;13(10):e0206256. PubMed PMID: PMC6209232. doi: 10.1371/journal.pone.0206256 
27. Mudd JC, Murphy P, Manion M, Debernardo R, Hardacre J, Ammori J, Hardy GA, Harding CV, Mahabaleshwar GH, Jain MK, Jacobson JM, Brooks AD, Lewis S, Schacker TW, Anderson J, Haddad EK, Cubas RA, Rodriguez B, Sieg SF, Lederman MM. Impaired T-cell responses to sphingosine-1-phosphate in HIV-1 infected lymph nodes. Blood. 2013;121(15):2914-22. PubMed PMID: PMC3624937. doi: 10.1182/blood-2012-07-445783

28. Zeng M, Southern PJ, Reilly CS, Beilman GJ, Chipman JG, Schacker TW, Haase AT. Lymphoid tissue damage in HIV-1 infection depletes naive T cells and limits T cell reconstitution after antiretroviral therapy. PLoS Pathog. 2012;8(1):e1002437. PubMed PMID: PMC3252371. doi: 10.1371/journal.ppat.1002437

29. Shive CL, Mudd JC, Funderburg NT, Sieg SF, Kyi B, Bazdar DA, Mangioni D, Gori A, Jacobson JM, Brooks AD, Hardacre J, Ammori J, Estes JD, Schacker TW, Rodriguez B, Lederman MM. Inflammatory cytokines drive CD4+ T-cell cycling and impaired responsiveness to interleukin 7: implications for immune failure in HIV disease. J Infect Dis. 2014;210(4):619-29. PubMed PMID: PMC4172041. doi: 10.1093/infdis/jiu125

30. Sherman KE, Abdel-Hameed E, Rouster SD, Shata MTM, Blackard JT, Safaie P, Kroner B, Preiss L, Horn PS, Kottilil S. Improvement in Hepatic Fibrosis Biomarkers Associated With Chemokine Receptor Inactivation Through Mutation or Therapeutic Blockade. Clin Infect Dis. 2019;68(11):1911-8. PubMed PMID: PMC6784280. doi: 10.1093/cid/ciy807

31. D’Antoni ML, Paul RH, Mitchell BI, Kohorn L, Fischer L, Lefebvre E, Seyedkazemi S, Nakamoto BK, Walker M, Kallianpur KJ, Ogata-Arakaki D, Ndhlovu LC, Shikuma C. Improved Cognitive Performance and Reduced Monocyte Activation in Virally Suppressed Chronic HIV After Dual CCR2 and CCR5 Antagonism. J Acquir Immune Defic Syndr. 2018;79(1):108-16. PubMed PMID: PMC6092236. doi: 10.1097/QAI.0000000000001752

32. Hunt PW, Shulman NS, Hayes TL, Dahl V, Somsouk M, Funderburg NT, McLaughlin B, Landay AL, Adeyemi O, Gilman LE, Clagett B, Rodriguez B, Martin JN, Schacker TW, Shacklett BL, Palmer S, Lederman MM, Deeks SG. The immunologic effects of maraviroc intensification in treated HIV-infected individuals with incomplete CD4+ T-cell recovery: a randomized trial. Blood. 2013;121(23):4635-46. PubMed PMID: PMC3685899. doi: 10.1182/ blood-2012-06-436345

33. Sauce D, Larsen M, Fastenackels S, Pauchard M, Ait-Mohand H, Schneider L, Guihot A, Boufassa F, Zaunders J, Iguertsira M, Bailey M, Gorochov G, Duvivier C, Carcelain G, Kelleher AD, Simon A, Meyer L, Costagliola D, Deeks SG, Lambotte O, Autran B, Hunt PW, Katlama C, Appay V. HIV disease progression despite suppression of viral replication is associated with exhaustion of lymphopoiesis. Blood. 2011;117(19):5142-51. PubMed PMID: PMC3109539. doi: 10.1182/blood-2011-01-331306

34. McNamara RP, Costantini LM, Myers TA, Schouest B, Maness NJ, Griffith JD, Damania BA, MacLean AG, Dittmer DP. Nef Secretion into Extracellular Vesicles or Exosomes Is Conserved across Human and Simian Immunodeficiency Viruses. MBio. 2018;9(1). PubMed PMID: PMC5801467. doi: 10.1128/mBio.02344-17 
35. Banga R, Procopio FA, Noto A, Pollakis G, Cavassini M, Ohmiti K, Corpataux JM, de Leval L, Pantaleo G, Perreau M. PD-1(+) and follicular helper T cells are responsible for persistent HIV-1 transcription in treated aviremic individuals. Nat Med. 2016;22(7):754-61. PubMed PMID. doi: 10.1038/nm.4113

36. McComsey GA, Daar ES, O’Riordan M, Collier AC, Kosmiski L, Santana JL, Fichtenbaum CJ, Fink H, Sax PE, Libutti DE, Gerschenson M. Changes in fat mitochondrial DNA and function in subjects randomized to abacavir-lamivudine or tenofovir DF-emtricitabine with atazanavir-ritonavir or efavirenz: AIDS Clinical Trials Group study A5224s, substudy of A5202. J Infect Dis. 2013;207(4):604-11. PubMed PMID: PMC3549598. doi: 10.1093/infdis/jis720

37. Venter WDF, Moorhouse M, Sokhela S, Fairlie L, Mashabane N, Masenya M, Serenata C, Akpomiemie G, Qavi A, Chandiwana N, Norris S, Chersich M, Clayden P, Abrams E, Arulappan N, Vos A, McCann K, Simmons B, Hill A. Dolutegravir plus Two Different Prodrugs of Tenofovir to Treat HIV. N Engl J Med. 2019;381(9):803-15. PubMed PMID. doi: 10.1056/NEJMoa1902824

38. Justice AC, Erlandson KM, Hunt PW, Landay A, Miotti P, Tracy RP. Can Biomarkers Advance HIV Research and Care in the Antiretroviral Therapy Era? J Infect Dis. 2018;217(4):5218. PubMed PMID: PMC5853399. doi: 10.1093/infdis/jix586

39. Ivanov, II, Atarashi K, Manel N, Brodie EL, Shima T, Karaoz U, Wei D, Goldfarb KC, Santee CA, Lynch SV, Tanoue T, Imaoka A, Itoh K, Takeda K, Umesaki Y, Honda K, Littman DR. Induction of intestinal Th17 cells by segmented filamentous bacteria. Cell. 2009;139(3):485-98. PubMed PMID: PMC2796826. doi: 10.1016/j.cell.2009.09.033

40. Schirmer M, Smeekens SP, Vlamakis H, Jaeger M, Oosting M, Franzosa EA, Horst RT, Jansen T, Jacobs L, Bonder MJ, Kurilshikov A, Fu J, Joosten LAB, Zhernakova A, Huttenhower C, Wijmenga C, Netea MG, Xavier RJ. Linking the Human Gut Microbiome to Inflammatory Cytokine Production Capacity. Cell. 2016;167(7):1897. PubMed PMID. doi: 10.1016/j. cell.2016.11.046

41. Omenetti S, Pizarro TT. The Treg/Th17 Axis: A Dynamic Balance Regulated by the Gut Microbiome. Front Immunol. 2015;6:639. PubMed PMID: PMC4681807. doi: 10.3389/fimmu.2015.00639

42. Brenchley JM, Price DA, Schacker TW, Asher TE, Silvestri G, Rao S, Kazzaz Z, Bornstein E, Lambotte O, Altmann D, Blazar BR, Rodriguez B, Teixeira-Johnson L, Landay A, Martin JN, Hecht FM, Picker LJ, Lederman MM, Deeks SG, Douek DC. Microbial translocation is a cause of systemic immune activation in chronic HIV infection. Nat Med. 2006;12(12):1365-71. PubMed PMID. doi: 10.1038/nm1511

43. Hunt PW, Sinclair E, Rodriguez B, Shive C, Clagett B, Funderburg N, Robinson J, Huang Y, Epling L, Martin JN, Deeks SG, Meinert CL, Van Natta ML, Jabs DA, Lederman MM. Gut epithelial barrier dysfunction and innate immune activation predict mortality in treated HIV infection. J Infect Dis. 2014;210(8):1228-38. PubMed PMID: PMC4192038. doi: 10.1093/infdis/ jiu238 
44. Veazey RS, DeMaria M, Chalifoux LV, Shvetz DE, Pauley DR, Knight HL, Rosenzweig M, Johnson RP, Desrosiers RC, Lackner AA. Gastrointestinal tract as a major site of CD4+ T cell depletion and viral replication in SIV infection. Science. 1998;280(5362):427-31. PubMed PMID. doi: 10.1126/science.280.5362.427

45. Mehandru S, Poles MA, Tenner-Racz K, Jean-Pierre P, Manuelli V, Lopez P, Shet A, Low A, Mohri H, Boden D, Racz P, Markowitz M. Lack of mucosal immune reconstitution during prolonged treatment of acute and early HIV-1 infection. PLoS Med. 2006;3(12):e484. PubMed PMID: PMC1762085. doi: 10.1371/journal.pmed.0030484

46. Rooks MG, Garrett WS. Gut microbiota, metabolites and host immunity. Nat Rev Immunol. 2016;16(6):341-52. PubMed PMID: PMC5541232. doi: 10.1038/nri.2016.42

47. Tang WH, Kitai T, Hazen SL. Gut Microbiota in Cardiovascular Health and Disease.

Circ Res. 2017;120(7):1183-96. PubMed PMID: PMC5390330. doi: 10.1161/CIRCRESAHA.117.309715

48. Tripathi A, Debelius J, Brenner DA, Karin M, Loomba R, Schnabl B, Knight R. The gut-liver axis and the intersection with the microbiome. Nat Rev Gastroenterol Hepatol. 2018;15(7):397411. PubMed PMID: PMC6319369. doi: 10.1038/s41575-018-0011-z

49. Sharon G, Sampson TR, Geschwind DH, Mazmanian SK. The Central Nervous System and the Gut Microbiome. Cell. 2016;167(4):915-32. PubMed PMID: PMC5127403. doi: 10.1016/j. cell.2016.10.027

50. Gopalakrishnan V, Helmink BA, Spencer CN, Reuben A, Wargo JA. The Influence of the Gut Microbiome on Cancer, Immunity, and Cancer Immunotherapy. Cancer Cell. 2018;33(4):570-80. PubMed PMID: PMC6529202. doi: 10.1016/j.ccell.2018.03.015

51. Elinav E, Garrett WS, Trinchieri G, Wargo J. The cancer microbiome. Nat Rev Cancer. 2019;19(7):371-6. PubMed PMID: PMC6700740. doi: 10.1038/s41568-019-0155-3

52. Levy M, Blacher E, Elinav E. Microbiome, metabolites and host immunity. Curr Opin Microbiol. 2017;35:8-15. PubMed PMID. doi: 10.1016/j.mib.2016.10.003

53. Postler TS, Ghosh S. Understanding the Holobiont: How Microbial Metabolites Affect Human Health and Shape the Immune System. Cell Metab. 2017;26(1):110-30. PubMed PMID: PMC5535818. doi: 10.1016/j.cmet.2017.05.008

54. Lozupone CA, Li M, Campbell TB, Flores SC, Linderman D, Gebert MJ, Knight R, Fontenot AP, Palmer BE. Alterations in the gut microbiota associated with HIV-1 infection. Cell Host Microbe. 2013;14(3):329-39. PubMed PMID: PMC3864811. doi: 10.1016/j.chom.2013.08.006

55. Vujkovic-Cvijin I, Dunham RM, Iwai S, Maher MC, Albright RG, Broadhurst MJ, Hernandez RD, Lederman MM, Huang Y, Somsouk M, Deeks SG, Hunt PW, Lynch SV, McCune JM. Dysbiosis of the gut microbiota is associated with HIV disease progression and tryptophan catabolism. Sci Transl Med. 2013;5(193):193ra91. PubMed PMID: PMC4094294. doi: 10.1126/ scitranslmed.3006438 
56. Dillon SM, Lee EJ, Kotter CV, Austin GL, Dong Z, Hecht DK, Gianella S, Siewe B, Smith DM, Landay AL, Robertson CE, Frank DN, Wilson CC. An altered intestinal mucosal microbiome in HIV-1 infection is associated with mucosal and systemic immune activation and endotoxemia. Mucosal Immunol. 2014;7(4):983-94. PubMed PMID: PMC4062575. doi: 10.1038/ mi.2013.116

57. Monaco CL, Gootenberg DB, Zhao G, Handley SA, Ghebremichael MS, Lim ES, Lankowski A, Baldridge MT, Wilen CB, Flagg M, Norman JM, Keller BC, Luevano JM, Wang D, Boum Y, Martin JN, Hunt PW, Bangsberg DR, Siedner MJ, Kwon DS, Virgin HW. Altered Virome and Bacterial Microbiome in Human Immunodeficiency Virus-Associated Acquired Immunodeficiency Syndrome. Cell Host Microbe. 2016;19(3):311-22. PubMed PMID: PMC4821831. doi: 10.1016/j.chom.2016.02.011

58. Noguera-Julian M, Rocafort M, Guillen Y, Rivera J, Casadella M, Nowak P, Hildebrand F, Zeller G, Parera M, Bellido R, Rodriguez C, Carrillo J, Mothe B, Coll J, Bravo I, Estany C, Herrero C, Saz J, Sirera G, Torrela A, Navarro J, Crespo M, Brander C, Negredo E, Blanco J, Guarner F, Calle ML, Bork P, Sonnerborg A, Clotet B, Paredes R. Gut Microbiota Linked to Sexual Preference and HIV Infection. EBioMedicine. 2016;5:135-46. PubMed PMID:

PMC4816837. doi: 10.1016/j.ebiom.2016.01.032

59. Rocafort M, Noguera-Julian M, Rivera J, Pastor L, Guillen Y, Langhorst J, Parera M, Mandomando I, Carrillo J, Urrea V, Rodriguez C, Casadella M, Calle ML, Clotet B, Blanco J, Naniche D, Paredes R. Evolution of the gut microbiome following acute HIV-1 infection. Microbiome. 2019;7(1):73. PubMed PMID: PMC6511141. doi: 10.1186/s40168-019-0687-5

60. Armstrong AJS, Shaffer M, Nusbacher NM, Griesmer C, Fiorillo S, Schneider JM, Preston Neff C, Li SX, Fontenot AP, Campbell T, Palmer BE, Lozupone CA. An exploration of Prevotella-rich microbiomes in HIV and men who have sex with men. Microbiome. 2018;6(1):198. PubMed PMID: PMC6219090. doi: 10.1186/s40168-018-0580-7

61. Vujkovic-Cvijin I, Somsouk M. HIV and the Gut Microbiota: Composition, Consequences, and Avenues for Amelioration. Curr HIV/AIDS Rep. 2019;16(3):204-13. PubMed PMID: PMC6579656. doi: 10.1007/s11904-019-00441-w

62. Wu GD, Chen J, Hoffmann C, Bittinger K, Chen YY, Keilbaugh SA, Bewtra M, Knights D, Walters WA, Knight R, Sinha R, Gilroy E, Gupta K, Baldassano R, Nessel L, Li H, Bushman FD, Lewis JD. Linking long-term dietary patterns with gut microbial enterotypes. Science. 2011;334(6052):105-8. PubMed PMID: PMC3368382. doi: 10.1126/science.1208344

63. Yatsunenko T, Rey FE, Manary MJ, Trehan I, Dominguez-Bello MG, Contreras M, Magris M, Hidalgo G, Baldassano RN, Anokhin AP, Heath AC, Warner B, Reeder J, Kuczynski J, Caporaso JG, Lozupone CA, Lauber C, Clemente JC, Knights D, Knight R, Gordon JI. Human gut microbiome viewed across age and geography. Nature. 2012;486(7402):222-7. PubMed PMID: PMC3376388. doi: 10.1038/nature11053

64. Neff CP, Krueger O, Xiong K, Arif S, Nusbacher N, Schneider JM, Cunningham AW, Armstrong A, Li S, McCarter MD, Campbell TB, Lozupone CA, Palmer BE. Fecal Microbiota Com- 
position Drives Immune Activation in HIV-infected Individuals. EBioMedicine. 2018;30:192202. PubMed PMID: PMC5952409. doi: 10.1016/j.ebiom.2018.03.024

65. Nowak P, Troseid M, Avershina E, Barqasho B, Neogi U, Holm K, Hov JR, Noyan K, Vesterbacka J, Svard J, Rudi K, Sonnerborg A. Gut microbiota diversity predicts immune status in HIV1 infection. AIDS. 2015;29(18):2409-18. PubMed PMID. doi: 10.1097/QAD.0000000000000869

66. Kaur US, Shet A, Rajnala N, Gopalan BP, Moar P, D H, Singh BP, Chaturvedi R, Tandon R. High Abundance of genus Prevotella in the gut of perinatally HIV-infected children is associated with IP-10 levels despite therapy. Sci Rep. 2018;8(1):17679. PubMed PMID: PMC6281660. doi: 10.1038/s41598-018-35877-4

67. Prasitsuebsai W, Sethaputra C, Lumbiganon P, Hansudewechakul R, Chokephaibulkit K, Truong KH, Nguyen LV, Mohd Razali KA, Nik Yusoff NK, Fong MS, Teeraananchai S, Ananworanich J, Durier N, Asia-Pacific TAAsgoI. Adherence to antiretroviral therapy, stigma and behavioral risk factors in HIV-infected adolescents in Asia. AIDS Care. 2018;30(6):727-33. PubMed PMID: PMC5912939. doi: 10.1080/09540121.2018.1425363

68. Vazquez-Castellanos JF, Serrano-Villar S, Latorre A, Artacho A, Ferrus ML, Madrid N, Vallejo A, Sainz T, Martinez-Botas J, Ferrando-Martinez S, Vera M, Dronda F, Leal M, Del Romero J, Moreno S, Estrada V, Gosalbes MJ, Moya A. Altered metabolism of gut microbiota contributes to chronic immune activation in HIV-infected individuals. Mucosal Immunol. 2015;8(4):760-72. PubMed PMID. doi: 10.1038/mi.2014.107

69. Hoel H, Hove-Skovsgaard M, Hov JR, Gaardbo JC, Holm K, Kummen M, Rudi K, Nwosu F, Valeur J, Gelpi M, Seljeflot I, Ueland PM, Gerstoft J, Ullum H, Aukrust P, Nielsen SD, Troseid M. Impact of HIV and Type 2 diabetes on Gut Microbiota Diversity, Tryptophan Catabolism and Endothelial Dysfunction. Sci Rep. 2018;8(1):6725. PubMed PMID: PMC5928109. doi: 10.1038/ s41598-018-25168-3

70. Vesterbacka J, Rivera J, Noyan K, Parera M, Neogi U, Calle M, Paredes R, Sonnerborg A, Noguera-Julian M, Nowak P. Richer gut microbiota with distinct metabolic profile in HIV infected Elite Controllers. Sci Rep. 2017;7(1):6269. PubMed PMID: PMC5524949. doi: 10.1038/ s41598-017-06675-1

71. Handley SA, Thackray LB, Zhao G, Presti R, Miller AD, Droit L, Abbink P, Maxfield LF, Kambal A, Duan E, Stanley K, Kramer J, Macri SC, Permar SR, Schmitz JE, Mansfield K, Brenchley JM, Veazey RS, Stappenbeck TS, Wang D, Barouch DH, Virgin HW. Pathogenic simian immunodeficiency virus infection is associated with expansion of the enteric virome. Cell. 2012;151(2):253-66. PubMed PMID: PMC3490196. doi: 10.1016/j.cell.2012.09.024

72. Wang Z, Klipfell E, Bennett BJ, Koeth R, Levison BS, Dugar B, Feldstein AE, Britt EB, Fu X, Chung YM, Wu Y, Schauer P, Smith JD, Allayee H, Tang WH, DiDonato JA, Lusis AJ, Hazen SL. Gut flora metabolism of phosphatidylcholine promotes cardiovascular disease. Nature. 2011;472(7341):57-63. PubMed PMID: PMC3086762. doi: 10.1038/nature09922

73. Tang WH, Wang Z, Levison BS, Koeth RA, Britt EB, Fu X, Wu Y, Hazen SL. Intestinal microbial metabolism of phosphatidylcholine and cardiovascular risk. N Engl J Med. 2013;368(17):1575-84. PubMed PMID: PMC3701945. doi: 10.1056/NEJMoa1 109400 
74. Dejea CM, Fathi P, Craig JM, Boleij A, Taddese R, Geis AL, Wu X, DeStefano Shields CE, Hechenbleikner EM, Huso DL, Anders RA, Giardiello FM, Wick EC, Wang H, Wu S, Pardoll DM, Housseau F, Sears CL. Patients with familial adenomatous polyposis harbor colonic biofilms containing tumorigenic bacteria. Science. 2018;359(6375):592-7. PubMed PMID: PMC5881113. doi: 10.1126/science.aah3648

75. Dejea CM, Wick EC, Hechenbleikner EM, White JR, Mark Welch JL, Rossetti BJ, Peterson SN, Snesrud EC, Borisy GG, Lazarev M, Stein E, Vadivelu J, Roslani AC, Malik AA, Wanyiri JW, Goh KL, Thevambiga I, Fu K, Wan F, Llosa N, Housseau F, Romans K, Wu X, McAllister FM, Wu S, Vogelstein B, Kinzler KW, Pardoll DM, Sears CL. Microbiota organization is a distinct feature of proximal colorectal cancers. Proc Natl Acad Sci U S A. 2014;111(51):18321-6. PubMed PMID: PMC4280621. doi: 10.1073/pnas.1406199111

76. Budden KF, Shukla SD, Rehman SF, Bowerman KL, Keely S, Hugenholtz P, Armstrong-James DPH, Adcock IM, Chotirmall SH, Chung KF, Hansbro PM. Functional effects of the microbiota in chronic respiratory disease. Lancet Respir Med. 2019;7(10):907-20. PubMed PMID. doi: 10.1016/S2213-2600(18)30510-1

77. Madsen K, Cornish A, Soper P, McKaigney C, Jijon H, Yachimec C, Doyle J, Jewell L, De Simone C. Probiotic bacteria enhance murine and human intestinal epithelial barrier function. Gastroenterology. 2001;121(3):580-91. PubMed PMID. doi: 10.1053/gast.2001.27224

78. Kelly CJ, Zheng L, Campbell EL, Saeedi B, Scholz CC, Bayless AJ, Wilson KE, Glover LE, Kominsky DJ, Magnuson A, Weir TL, Ehrentraut SF, Pickel C, Kuhn KA, Lanis JM, Nguyen V, Taylor CT, Colgan SP. Crosstalk between Microbiota-Derived Short-Chain Fatty Acids and Intestinal Epithelial HIF Augments Tissue Barrier Function. Cell Host Microbe. 2015;17(5):662-71. PubMed PMID: PMC4433427. doi: 10.1016/j.chom.2015.03.005

79. Franzosa EA, Sirota-Madi A, Avila-Pacheco J, Fornelos N, Haiser HJ, Reinker S, Vatanen T, Hall AB, Mallick H, McIver LJ, Sauk JS, Wilson RG, Stevens BW, Scott JM, Pierce K, Deik AA, Bullock K, Imhann F, Porter JA, Zhernakova A, Fu J, Weersma RK, Wijmenga C, Clish CB, Vlamakis H, Huttenhower C, Xavier RJ. Gut microbiome structure and metabolic activity in inflammatory bowel disease. Nat Microbiol. 2019;4(2):293-305. PubMed PMID: PMC6342642. doi: 10.1038/s41564-018-0306-4

80. Weingarden AR, Vaughn BP. Intestinal microbiota, fecal microbiota transplantation, and inflammatory bowel disease. Gut Microbes. 2017;8(3):238-52. PubMed PMID: PMC5479396. doi: 10.1080/19490976.2017.1290757

81. Kardashian A, Ma Y, Yin MT, Scherzer R, Nolan O, Aweeka F, Tien PC, Price JC. High Kynurenine:Tryptophan Ratio Is Associated With Liver Fibrosis in HIV-Monoinfected and HIV/Hepatitis C Virus-Coinfected Women. Open Forum Infect Dis. 2019;6(7):ofz281. PubMed PMID: PMC6612851. doi: 10.1093/ofid/ofz281

82. Sinha A, Ma Y, Scherzer R, Rahalkar S, Neilan BD, Crane H, Drozd D, Martin J, Deeks SG, Hunt P, Hsue PY. Carnitine Is Associated With Atherosclerotic Risk and Myocardial Infarction in HIV -Infected Adults. J Am Heart Assoc. 2019;8(9):e011037. PubMed PMID: PMC6512101. doi: 10.1161/JAHA.118.011037 
83. Kehrmann J, Menzel J, Saeedghalati M, Obeid R, Schulze C, Holzendorf V, Farahpour F, Reinsch N, Klein-Hitpass L, Streeck H, Hoffmann D, Buer J, Esser S, Group H-HS. Gut Microbiota in Human Immunodeficiency Virus-Infected Individuals Linked to Coronary Heart Disease. J Infect Dis. 2019;219(3):497-508. PubMed PMID. doi: 10.1093/infdis/jiy524

84. Missailidis C, Neogi U, Stenvinkel P, Troseid M, Nowak P, Bergman P. The microbial metabolite trimethylamine-N-oxide in association with inflammation and microbial dysregulation in three HIV cohorts at various disease stages. AIDS. 2018;32(12):1589-98. PubMed PMID. doi: 10.1097/QAD.0000000000001813

85. Keegan MR, Chittiprol S, Letendre SL, Winston A, Fuchs D, Boasso A, Iudicello J, Ellis RJ. Tryptophan Metabolism and Its Relationship with Depression and Cognitive Impairment Among HIV-infected Individuals. Int J Tryptophan Res. 2016;9:79-88. PubMed PMID: PMC5083113. doi: 10.4137/IJTR.S36464

86. Cassol E, Misra V, Morgello S, Kirk GD, Mehta SH, Gabuzda D. Altered Monoamine and Acylcarnitine Metabolites in HIV-Positive and HIV-Negative Subjects With Depression. J Acquir Immune Defic Syndr. 2015;69(1):18-28. PubMed PMID: PMC4562456. doi: 10.1097/ QAI.0000000000000551

87. Martinez P, Tsai AC, Muzoora C, Kembabazi A, Weiser SD, Huang Y, Haberer JE, Martin JN, Bangsberg DR, Hunt PW. Reversal of the Kynurenine pathway of tryptophan catabolism may improve depression in ART-treated HIV-infected Ugandans. J Acquir Immune Defic Syndr. 2014;65(4):456-62. PubMed PMID: PMC3943704. doi: 10.1097/QAI.0000000000000062

88. Pinto-Cardoso S, Klatt NR, Reyes-Teran G. Impact of antiretroviral drugs on the microbiome: unknown answers to important questions. Curr Opin HIV AIDS. 2018;13(1):53-60. PubMed PMID: PMC5718259. doi: 10.1097/COH.0000000000000428

89. Villanueva-Millan MJ, Perez-Matute P, Recio-Fernandez E, Lezana Rosales JM, Oteo JA. Differential effects of antiretrovirals on microbial translocation and gut microbiota composition of HIV-infected patients. J Int AIDS Soc. 2017;20(1):21526. PubMed PMID: PMC5467634. doi: 10.7448/IAS.20.1.21526

90. Pinto-Cardoso S, Lozupone C, Briceno O, Alva-Hernandez S, Tellez N, Adriana A, Murakami-Ogasawara A, Reyes-Teran G. Fecal Bacterial Communities in treated HIV infected individuals on two antiretroviral regimens. Sci Rep. 2017;7:43741. PubMed PMID: PMC5338340. doi: $10.1038 /$ srep43741

91. Abdool Karim SS, Baxter C, Passmore JS, McKinnon LR, Williams BL. The genital tract and rectal microbiomes: their role in HIV susceptibility and prevention in women. J Int AIDS Soc. 2019;22(5):e25300. PubMed PMID: PMC6541743. doi: 10.1002/jia2.25300

92. Anderson D, Politch JA, Pudney J. HIV infection and immune defense of the penis. Am J Reprod Immunol. 2011;65(3):220-9. PubMed PMID: PMC3076079. doi: 10.1111/j.16000897.2010.00941.x 
93. Williams WB, Han Q, Haynes BF. Cross-reactivity of HIV vaccine responses and the microbiome. Curr Opin HIV AIDS. 2018;13(1):9-14. PubMed PMID: PMC5890927. doi: 10.1097/ COH.0000000000000423

94. Williams WB, Liao HX, Moody MA, Kepler TB, Alam SM, Gao F, Wiehe K, Trama AM, Jones K, Zhang R, Song H, Marshall DJ, Whitesides JF, Sawatzki K, Hua A, Liu P, Tay MZ, Seaton KE, Shen X, Foulger A, Lloyd KE, Parks R, Pollara J, Ferrari G, Yu JS, Vandergrift N, Montefiori DC, Sobieszczyk ME, Hammer S, Karuna S, Gilbert P, Grove D, Grunenberg N, McElrath MJ, Mascola JR, Koup RA, Corey L, Nabel GJ, Morgan C, Churchyard G, Maenza J, Keefer M, Graham BS, Baden LR, Tomaras GD, Haynes BF. HIV-1 VACCINES. Diversion of HIV-1 vaccine-induced immunity by gp41-microbiota cross-reactive antibodies. Science. 2015;349(6249):aab1253. PubMed PMID: PMC4562404. doi: 10.1126/science.aab1253

95. Klatt NR, Cheu R, Birse K, Zevin AS, Perner M, Noel-Romas L, Grobler A, Westmacott G, Xie IY, Butler J, Mansoor L, McKinnon LR, Passmore JS, Abdool Karim Q, Abdool Karim SS, Burgener AD. Vaginal bacteria modify HIV tenofovir microbicide efficacy in African women. Science. 2017;356(6341):938-45. PubMed PMID. doi: 10.1126/science.aai9383

96. Gopalakrishnan V, Spencer CN, Nezi L, Reuben A, Andrews MC, Karpinets TV, Prieto PA, Vicente D, Hoffman K, Wei SC, Cogdill AP, Zhao L, Hudgens CW, Hutchinson DS, Manzo T, Petaccia de Macedo M, Cotechini T, Kumar T, Chen WS, Reddy SM, Szczepaniak Sloane R, Galloway-Pena J, Jiang H, Chen PL, Shpall EJ, Rezvani K, Alousi AM, Chemaly RF, Shelburne S, Vence LM, Okhuysen PC, Jensen VB, Swennes AG, McAllister F, Marcelo Riquelme Sanchez E, Zhang Y, Le Chatelier E, Zitvogel L, Pons N, Austin-Breneman JL, Haydu LE, Burton EM, Gardner JM, Sirmans E, Hu J, Lazar AJ, Tsujikawa T, Diab A, Tawbi H, Glitza IC, Hwu WJ, Patel SP, Woodman SE, Amaria RN, Davies MA, Gershenwald JE, Hwu P, Lee JE, Zhang J, Coussens LM, Cooper ZA, Futreal PA, Daniel CR, Ajami NJ, Petrosino JF, Tetzlaff MT, Sharma P, Allison JP, Jenq RR, Wargo JA. Gut microbiome modulates response to anti-PD-1 immunotherapy in melanoma patients. Science. 2018;359(6371):97-103. PubMed PMID: PMC5827966. doi: 10.1126/science.aan4236

97. Vetizou M, Pitt JM, Daillere R, Lepage P, Waldschmitt N, Flament C, Rusakiewicz S, Routy B, Roberti MP, Duong CP, Poirier-Colame V, Roux A, Becharef S, Formenti S, Golden E, Cording S, Eberl G, Schlitzer A, Ginhoux F, Mani S, Yamazaki T, Jacquelot N, Enot DP, Berard M, Nigou J, Opolon P, Eggermont A, Woerther PL, Chachaty E, Chaput N, Robert C, Mateus C, Kroemer G, Raoult D, Boneca IG, Carbonnel F, Chamaillard M, Zitvogel L. Anticancer immunotherapy by CTLA-4 blockade relies on the gut microbiota. Science. 2015;350(6264):1079-84. PubMed PMID: PMC4721659. doi: 10.1126/science.aad1329

98. Sivan A, Corrales L, Hubert N, Williams JB, Aquino-Michaels K, Earley ZM, Benyamin FW, Lei YM, Jabri B, Alegre ML, Chang EB, Gajewski TF. Commensal Bifidobacterium promotes antitumor immunity and facilitates anti-PD-L1 efficacy. Science. 2015;350(6264):1084-9. PubMed PMID: PMC4873287. doi: 10.1126/science.aac4255

99. Overton ET, Yeh E, Presti R, Jacobson J, Williams B, Wilson C, Landay A, Brenchley J, Dube M, Fichtenbaum CJ, Utay NS, Kitch DW, Andrade A. Assessing the Probiotic Effect in Treated HIV: Results of ACTG A5350. CROI; Seattle, WA2019. 
100. Wada N, Jacobson LP, Cohen M, French A, Phair J, Munoz A. Cause-specific life expectancies after 35 years of age for human immunodeficiency syndrome-infected and human immunodeficiency syndrome-negative individuals followed simultaneously in long-term cohort studies, 1984-2008. Am J Epidemiol. 2013;177(2):116-25. PubMed PMID: PMC3590031. doi: 10.1093/ aje/kws321

101. High KP, Brennan-Ing M, Clifford DB, Cohen MH, Currier J, Deeks SG, Deren S, Effros RB, Gebo K, Goronzy JJ, Justice AC, Landay A, Levin J, Miotti PG, Munk RJ, Nass H, Rinaldo CR, Jr., Shlipak MG, Tracy R, Valcour V, Vance DE, Walston JD, Volberding P, HIV OARWGo, Aging. HIV and aging: state of knowledge and areas of critical need for research. A report to the NIH Office of AIDS Research by the HIV and Aging Working Group. J Acquir Immune Defic Syndr. 2012;60 Suppl 1:S1-18. PubMed PMID: PMC3413877. doi: 10.1097/ QAI.0b013e31825a3668

102. Cole JH, Underwood J, Caan MW, De Francesco D, van Zoest RA, Leech R, Wit FW, Portegies P, Geurtsen GJ, Schmand BA, Schim van der Loeff MF, Franceschi C, Sabin CA, Majoie CB, Winston A, Reiss P, Sharp DJ, collaboration C. Increased brain-predicted aging in treated HIV disease. Neurology. 2017;88(14):1349-57. PubMed PMID: PMC5379929. doi: 10.1212/ WNL.0000000000003790

103. Guaraldi G, Orlando G, Zona S, Menozzi M, Carli F, Garlassi E, Berti A, Rossi E, Roverato A, Palella F. Premature age-related comorbidities among HIV-infected persons compared with the general population. Clin Infect Dis. 2011;53(11):1120-6. PubMed PMID. doi: 10.1093/cid/ cir627

104. Schrack JA, Althoff KN, Jacobson LP, Erlandson KM, Jamieson BD, Koletar SL, Phair J, Ferrucci L, Brown TT, Margolick JB, Multicenter ACS. Accelerated Longitudinal Gait Speed Decline in HIV-Infected Older Men. J Acquir Immune Defic Syndr. 2015;70(4):370-6. PubMed PMID: PMC4624470. doi: 10.1097/QAI.0000000000000731

105. Schrack JA, Jacobson LP, Althoff KN, Erlandson KM, Jamieson BD, Koletar SL, Phair J, Brown TT, Margolick JB, Multicenter ACS. Effect of HIV-infection and cumulative viral load on age-related decline in grip strength. AIDS. 2016;30(17):2645-52. PubMed PMID: PMC5083134. doi: 10.1097/QAD.0000000000001245

106. Althoff KN, Jacobson LP, Cranston RD, Detels R, Phair JP, Li X, Margolick JB, Multicenter ACS. Age, comorbidities, and AIDS predict a frailty phenotype in men who have sex with men. J Gerontol A Biol Sci Med Sci. 2014;69(2):189-98. PubMed PMID: PMC4038242. doi: 10.1093/ gerona/glt148

107. Guaraldi G, De Francesco D, Milic J, Franconi I, Mussini C, Falutz J, Cesari M. The Interplay Between Age and Frailty in People Living With HIV: Results From an 11-Year Follow-up Observational Study. Open Forum Infect Dis. 2019;6(5):ofz199. PubMed PMID: PMC6524826. doi: 10.1093/ofid/ofz199

108. Lagathu C, Cossarizza A, Bereziat V, Nasi M, Capeau J, Pinti M. Basic science and pathogenesis of ageing with HIV: potential mechanisms and biomarkers. AIDS. 2017;31 Suppl 2:S105-S19. PubMed PMID. doi: 10.1097/QAD.0000000000001441 
109. Rasmussen LD, May MT, Kronborg G, Larsen CS, Pedersen C, Gerstoft J, Obel N. Time trends for risk of severe age-related diseases in individuals with and without HIV infection in Denmark: a nationwide population-based cohort study. Lancet HIV. 2015;2(7):e288-98. PubMed PMID. doi: 10.1016/S2352-3018(15)00077-6

110. Kuller LH, Tracy R, Belloso W, De Wit S, Drummond F, Lane HC, Ledergerber B, Lundgren J, Neuhaus J, Nixon D, Paton NI, Neaton JD, Group ISS. Inflammatory and coagulation biomarkers and mortality in patients with HIV infection. PLoS Med. 2008;5(10):e203. PubMed PMID: PMC2570418. doi: 10.1371/journal.pmed.0050203

111. Margolick JB, Bream JH, Nilles TL, Li H, Langan SJ, Deng S, Wang R, Wada N, Leng SX. Relationship Between T-Cell Responses to CMV, Markers of Inflammation, and Frailty in HIV-uninfected and HIV-infected Men in the Multicenter AIDS Cohort Study. J Infect Dis. 2018;218(2):249-58. PubMed PMID: PMC6009694. doi: 10.1093/infdis/jiy005

112. Lee SA, Sinclair E, Jain V, Huang Y, Epling L, Van Natta M, Meinert CL, Martin JN, McCune JM, Deeks SG, Lederman MM, Hecht FM, Hunt PW. Low proportions of CD28- CD8+ T cells expressing CD57 can be reversed by early ART initiation and predict mortality in treated HIV infection. J Infect Dis. 2014;210(3):374-82. PubMed PMID: PMC4110459. doi: 10.1093/ infdis/jiu109

113. Lee SA, Sinclair E, Hatano H, Hsue PY, Epling L, Hecht FM, Bangsberg DR, Martin JN, McCune JM, Deeks SG, Hunt PW. Impact of HIV on CD8+ T cell CD57 expression is distinct from that of CMV and aging. PLoS One. 2014;9(2):e89444. PubMed PMID: PMC3937334. doi: 10.1371/journal.pone.0089444

114. Whetten K, Reif S, Whetten R, Murphy-McMillan LK. Trauma, mental health, distrust, and stigma among HIV-positive persons: implications for effective care. Psychosom Med. 2008;70(5):531-8. PubMed PMID. doi: 10.1097/PSY.0b013e31817749dc

115. George VK, Pallikkuth S, Parmigiani A, Alcaide M, Fischl M, Arheart KL, Pahwa S. HIV infection Worsens Age-Associated Defects in Antibody Responses to Influenza Vaccine. J Infect Dis. 2015;211(12):1959-68. PubMed PMID: PMC4836723. doi: 10.1093/infdis/jiu840

116. de Armas LR, Pallikkuth S, George V, Rinaldi S, Pahwa R, Arheart KL, Pahwa S. Reevaluation of immune activation in the era of cART and an aging HIV-infected population. JCI Insight. 2017;2(20). PubMed PMID: PMC5846952. doi: 10.1172/jci.insight.95726

117. Pallikkuth S, De Armas LR, Pahwa R, Rinaldi S, George VK, Sanchez CM, Pan L, Dickinson G, Rodriguez A, Fischl M, Alcaide M, Pahwa S. Impact of aging and HIV infection on serologic response to seasonal influenza vaccination. AIDS. 2018;32(9):1085-94. PubMed PMID: PMC6574117. doi: 10.1097/QAD.0000000000001774

118. Pallikkuth S, de Armas LR, Rinaldi S, George VK, Pan L, Arheart KL, Pahwa R, Pahwa S. Dysfunctional peripheral T follicular helper cells dominate in people with impaired influenza vaccine responses: Results from the FLORAH study. PLoS Biol. 2019;17(5):e3000257. PubMed PMID: PMC6542545. doi: 10.1371/journal.pbio.3000257 
119. Furler RL, Newcombe KL, Del Rio Estrada PM, Reyes-Teran G, Uittenbogaart CH, Nixon DF. Histoarchitectural Deterioration of Lymphoid Tissues in HIV-1 Infection and in Aging. AIDS Res Hum Retroviruses. 2019;35(11-12):1148-59. PubMed PMID: PMC6862967. doi: 10.1089/ AID.2019.0156

120. Tavenier J, Margolick JB, Leng SX. T-cell immunity against cytomegalovirus in HIV infection and aging: relationships with inflammation, immune activation, and frailty. Med Microbiol Immunol. 2019;208(3-4):289-94. PubMed PMID: PMC6635075. doi: 10.1007/s00430-01900591-z

121. Cooper CL, Galanakis C, Donelle J, Kwong J, Boyd R, Boucher L, Kendall CE. HCV-infected individuals have higher prevalence of comorbidity and multimorbidity: a retrospective cohort study. BMC Infect Dis. 2019;19(1):712. PubMed PMID: PMC6706878. doi: 10.1186/ s12879-019-4315-6

122. Lu AT, Quach A, Wilson JG, Reiner AP, Aviv A, Raj K, Hou L, Baccarelli AA, Li Y, Stewart JD, Whitsel EA, Assimes TL, Ferrucci L, Horvath S. DNA methylation GrimAge strongly predicts lifespan and healthspan. Aging (Albany NY). 2019;11(2):303-27. PubMed PMID: PMC6366976. doi: 10.18632/aging.101684

123. Gross AM, Jaeger PA, Kreisberg JF, Licon K, Jepsen KL, Khosroheidari M, Morsey BM, Swindells S, Shen H, Ng CT, Flagg K, Chen D, Zhang K, Fox HS, Ideker T. Methylome-wide Analysis of Chronic HIV Infection Reveals Five-Year Increase in Biological Age and Epigenetic Targeting of HLA. Mol Cell. 2016;62(2):157-68. PubMed PMID: PMC4995115. doi: 10.1016/j. molcel.2016.03.019

124. Theurey P, Pizzo P. The Aging Mitochondria. Genes (Basel). 2018;9(1). PubMed PMID: PMC5793175. doi: 10.3390/genes9010022

125. Franceschi C, Campisi J. Chronic inflammation (inflammaging) and its potential contribution to age-associated diseases. J Gerontol A Biol Sci Med Sci. 2014;69 Suppl 1:S4-9. PubMed PMID. doi: 10.1093/gerona/glu057

126. van Deursen JM. The role of senescent cells in ageing. Nature. 2014;509(7501):439-46. PubMed PMID: PMC4214092. doi: 10.1038/nature13193

127. Coppe JP, Patil CK, Rodier F, Sun Y, Munoz DP, Goldstein J, Nelson PS, Desprez PY, Campisi J. Senescence-associated secretory phenotypes reveal cell-nonautonomous functions of oncogenic RAS and the p53 tumor suppressor. PLoS Biol. 2008;6(12):2853-68. PubMed PMID: PMC2592359. doi: 10.1371/journal.pbio.0060301

128. Prata L, Ovsyannikova IG, Tchkonia T, Kirkland JL. Senescent cell clearance by the immune system: Emerging therapeutic opportunities. Semin Immunol. 2019:101275. PubMed PMID. doi: 10.1016/j.smim.2019.04.003

129. Coppe JP, Desprez PY, Krtolica A, Campisi J. The senescence-associated secretory phenotype: the dark side of tumor suppression. Annu Rev Pathol. 2010;5:99-118. PubMed PMID: PMC4166495. doi: 10.1146/annurev-pathol-121808-102144 
130. Zhu Y, Armstrong JL, Tchkonia T, Kirkland JL. Cellular senescence and the senescent secretory phenotype in age-related chronic diseases. Curr Opin Clin Nutr Metab Care. 2014;17(4):324-8. PubMed PMID. doi: 10.1097/MCO.0000000000000065

131. Kennedy BK, Berger SL, Brunet A, Campisi J, Cuervo AM, Epel ES, Franceschi C, Lithgow GJ, Morimoto RI, Pessin JE, Rando TA, Richardson A, Schadt EE, Wyss-Coray T, Sierra F. Geroscience: linking aging to chronic disease. Cell. 2014;159(4):709-13. PubMed PMID: PMC4852871. doi: 10.1016/j.cell.2014.10.039

132. Effros RB, Allsopp R, Chiu CP, Hausner MA, Hirji K, Wang L, Harley CB, Villeponteau B, West MD, Giorgi JV. Shortened telomeres in the expanded CD28-CD8+ cell subset in HIV disease implicate replicative senescence in HIV pathogenesis. AIDS. 1996;10(8):F17-22. PubMed PMID. doi: 10.1097/00002030-199607000-00001

133. Babu H, Ambikan AT, Gabriel EE, Svensson Akusjarvi S, Palaniappan AN, Sundaraj V, Mupanni NR, Sperk M, Cheedarla N, Sridhar R, Tripathy SP, Nowak P, Hanna LE, Neogi U. Systemic Inflammation and the Increased Risk of Inflamm-Aging and Age-Associated Diseases in People Living With HIV on Long Term Suppressive Antiretroviral Therapy. Front Immunol. 2019;10:1965. PubMed PMID: PMC6718454. doi: 10.3389/fimmu.2019.01965

134. Rickabaugh TM, Kilpatrick RD, Hultin LE, Hultin PM, Hausner MA, Sugar CA, Althoff KN, Margolick JB, Rinaldo CR, Detels R, Phair J, Effros RB, Jamieson BD. The dual impact of HIV-1 infection and aging on naive CD4 T-cells: additive and distinct patterns of impairment. PLoS One. 2011;6(1):e16459. PubMed PMID: PMC3027697. doi: 10.1371/journal. pone. 0016459

135. Killian MS, Monteiro J, Matud J, Hultin LE, Hausner MA, Yang OO, Gregersen PK, Detels R, Giorgi JV, Jamieson BD. Persistent alterations in the T-cell repertoires of HIV-1-infected and at-risk uninfected men. AIDS. 2004;18(2):161-70. PubMed PMID. doi: 10.1097/00002030200401230-00004

136. Pathai S, Lawn SD, Gilbert CE, McGuinness D, McGlynn L, Weiss HA, Port J, Christ T, Barclay K, Wood R, Bekker LG, Shiels PG. Accelerated biological ageing in HIV-infected individuals in South Africa: a case-control study. AIDS. 2013;27(15):2375-84. PubMed PMID: PMC3805356. doi: 10.1097/QAD.0b013e328363bf7f

137. Kaner JD, Thibaud S, Jasra S, Wang Y, Janakiram M, Sharma A, Sridharan A, Elias H, Polineni R, Assal A, Weiss L, Braunschweig I, Steidl U, Pradhan K, Shastri A, Chaitowitz M, Zingman B, Will B, Mantzaris I, Verma A. HIV portends a poor prognosis in myelodysplastic syndromes. Leuk Lymphoma. 2019:1-7. PubMed PMID. doi: 10.1080/10428194.2019.1633631

138. Dhurve SA, Dhurve AS. Bone Marrow Abnormalities in HIV Disease. Mediterr J Hematol Infect Dis. 2013;5(1):e2013033. PubMed PMID: PMC3684351. doi: 10.4084/MJHID.2013.033

139. Szaniawski MA, Spivak AM. Senotherapeutics for HIV and aging. Curr Opin HIV AIDS. 2019. PubMed PMID. doi: 10.1097/COH.0000000000000609 
140. Baker DJ, Wijshake T, Tchkonia T, LeBrasseur NK, Childs BG, van de Sluis B, Kirkland JL, van Deursen JM. Clearance of p16Ink4a-positive senescent cells delays ageing-associated disorders. Nature. 2011;479(7372):232-6. PubMed PMID: PMC3468323. doi: 10.1038/nature10600

141. Niedernhofer LJ, Robbins PD. Senotherapeutics for healthy ageing. Nat Rev Drug Discov. 2018;17(5):377. PubMed PMID. doi: 10.1038/nrd.2018.44

142. Justice JN, Nambiar AM, Tchkonia T, LeBrasseur NK, Pascual R, Hashmi SK, Prata L, Masternak MM, Kritchevsky SB, Musi N, Kirkland JL. Senolytics in idiopathic pulmonary fibrosis: Results from a first-in-human, open-label, pilot study. EBioMedicine. 2019;40:554-63. PubMed PMID: PMC6412088. doi: 10.1016/j.ebiom.2018.12.052

143. Routy JP, Isnard S, Mehraj V, Ostrowski M, Chomont N, Ancuta P, Ponte R, Planas D, Dupuy FP, Angel JB, Lilac Study G. Effect of metformin on the size of the HIV reservoir in non-diabetic ART-treated individuals: single-arm non-randomised Lilac pilot study protocol. BMJ Open. 2019;9(4):e028444. PubMed PMID: PMC6500211. doi: 10.1136/bmjopen-2018-028444

144. Miller RA, Harrison DE, Astle CM, Fernandez E, Flurkey K, Han M, Javors MA, Li X, Nadon NL, Nelson JF, Pletcher S, Salmon AB, Sharp ZD, Van Roekel S, Winkleman L, Strong R. Rapamycin-mediated lifespan increase in mice is dose and sex dependent and metabolically distinct from dietary restriction. Aging Cell. 2014;13(3):468-77. PubMed PMID: PMC4032600. doi: $10.1111 /$ acel.12194

145. Mannick JB, Del Giudice G, Lattanzi M, Valiante NM, Praestgaard J, Huang B, Lonetto MA, Maecker HT, Kovarik J, Carson S, Glass DJ, Klickstein LB. mTOR inhibition improves immune function in the elderly. Sci Transl Med. 2014;6(268):268ra179. PubMed PMID. doi: 10.1126/scitranslmed.3009892

146. Pandrea I, Landay A, Wilson C, Stock J, Tracy R, Apetrei C. Using the pathogenic and nonpathogenic nonhuman primate model for studying non-AIDS comorbidities. Curr HIV/AIDS Rep. 2015;12(1):54-67. PubMed PMID: PMC4369284. doi: 10.1007/s11904-014-0245-5

147. Mattison JA, Vaughan KL. An overview of nonhuman primates in aging research. Exp Gerontol. 2017;94:41-5. PubMed PMID: PMC5466843. doi: 10.1016/j.exger.2016.12.005

148. Zheng HY, Zhang MX, Chen M, Jiang J, Song JH, Lian XD, Tian RR, Zhang XL, Zhang LT, Pang W, Zhang GH, Zheng YT. Accelerated disease progression and robust innate host response in aged SIVmac239-infected Chinese rhesus macaques is associated with enhanced immunosenescence. Sci Rep. 2017;7(1):37. PubMed PMID: PMC5428349. doi: 10.1038/s41598017-00084-0

149. Bissel SJ, Gurnsey K, Jedema HP, Smith NF, Wang G, Bradberry CW, Wiley CA. Aged Chinese-origin rhesus macaques infected with SIV develop marked viremia in absence of clinical disease, inflammation or cognitive impairment. Retrovirology. 2018;15(1):17. PubMed PMID: PMC5796498. doi: 10.1186/s12977-018-0400-y 


\section{FOOTNOTES}

Submitted March 9, 2020 | Accepted March 10, 2020 | Published June 17, 2020

\section{COPYRIGHT}

Copyright () 2020 Pathogens and Immunity.

This is an open-access article distributed under the terms of the Creative Commons Attribution 4.0 International License. 